\title{
Article \\ Criticality and Life-Cycle Assessment of Materials Used in Fuel-Cell and Hydrogen Technologies
}

\author{
Mitja Mori (D, Rok Stropnik, Mihael Sekavčnik and Andrej Lotrič *(D) \\ Faculty of Mechanical Engineering, University of Ljubljana, Aškerčeva 6, 1000 Ljubljana, Slovenia; \\ mitja.mori@fs.uni-lj.si (M.M.); rok.stropnik@fs.uni-lj.si (R.S.); mihael.sekavcnik@fs.uni-lj.si (M.S.) \\ * Correspondence: andrej.lotric@fs.uni-lj.si
}

Citation: Mori, M.; Stropnik, R.; Sekavčnik, M.; Lotrič, A. Criticality and Life-Cycle Assessment of Materials Used in Fuel-Cell and Hydrogen Technologies. Sustainability 2021, 13, 3565. https://doi.org/ $10.3390 /$ su13063565

Academic Editor: Marc A. Rosen

Received: 31 December 2020

Accepted: 14 March 2021

Published: 23 March 2021

Publisher's Note: MDPI stays neutral with regard to jurisdictional claims in published maps and institutional affiliations.

Copyright: (C) 2021 by the authors. Licensee MDPI, Basel, Switzerland. This article is an open access article distributed under the terms and conditions of the Creative Commons Attribution (CC BY) license (https:// creativecommons.org/licenses/by/ $4.0 /)$.

\begin{abstract}
The purpose of this paper is to obtain relevant data on materials that are the most commonly used in fuel-cell and hydrogen technologies. The focus is on polymer-electrolyte-membrane fuel cells, solid-oxide fuel cells, polymer-electrolyte-membrane water electrolysers and alkaline water electrolysers. An innovative, methodological approach was developed for a preliminary material assessment of the four technologies. This methodological approach leads to a more rapid identification of the most influential or critical materials that substantially increase the environmental impact of fuel-cell and hydrogen technologies. The approach also assisted in amassing the life-cycle inventories-the emphasis here is on the solid-oxide fuel-cell technology because it is still in its early development stage and thus has a deficient materials' database- - that were used in a life-cycle assessment for an in-depth material-criticality analysis. All the listed materials-that either are or could potentially be used in these technologies-were analysed to give important information for the fuel-cell and hydrogen industries, the recycling industry, the hydrogen economy, as well as policymakers. The main conclusion from the life-cycle assessment is that the polymer-electrolytemembrane water electrolysers have the highest environmental impacts; lower impacts are seen in polymer-electrolyte-membrane fuel cells and solid-oxide fuel cells, while the lowest impacts are observed in alkaline water electrolysers. The results of the material assessment are presented together for all the considered materials, but also separately for each observed technology.
\end{abstract}

Keywords: critical materials; fuel cells; electrolysers; hydrogen technologies; criticality; life-cycle assessment

\section{Introduction}

There are major concerns about negative environmental impacts. The Paris agreement, which was signed by 195 countries, is a further attempt to enforce a global action plan to mitigate the problems of climate change [1]. In addition, the European Union has set itself the very challenging goal of achieving carbon neutrality by 2050 [2]. For these and many other reasons, decarbonisation of the energy, transport and industrial sectors is necessary, and according to Ref. [3], it is expected that hydrogen will play an important role in this transition. The unique properties of hydrogen enable fuel-cell and hydrogen (FCH) technologies to be an alternative and complementary solution to conventional power-generation systems. The basic concept is to generate green hydrogen with water electrolysis using surplus electricity from renewable energy sources. State-of-the-art, commercial FCH technologies are nearly mature enough for deployment; however, certain roadmaps regarding the infrastructure roll-out need to be followed [4] and particular societal barriers still need to be addressed [5]. One factor that also hinders the widespread deployment of FCH technologies is the lack of well-defined end-of-life (EoL) strategies [6]. From the sustainability point of view, it is necessary to reduce the consumption of virgin critical materials by recycling and in doing so reduce the environmental impacts of the production stage [6]. 
The most market-mature hydrogen-production technologies using water electrolysis are alkaline water electrolysers (AWEs) and polymer-electrolyte-membrane water electrolysers (PEMWEs) [7,8]. On the other hand, among the fuel-cell technologies, polymerelectrolyte-membrane fuel cells (PEMFCs) and solid-oxide fuel cells (SOFCs) both have a relatively high technological maturity and large research-and-development activities $[9,10]$. PEMFCs and SOFCs also have the possibility to be used in a variety of applications [11] and dominate the market for small, stationary combined-heat-and-power installations (i.e., for domestic use) [12,13]. In general, the most critical materials in FCH technologies are those that are used as catalysts for electrochemical reactions. This applies to AWEs, PEMWEs and PEMFCs, where the catalysts are generally based on platinum-group metals (PGMs). Due to a different mode of operation and higher temperatures, a SOFC's core components are mainly based on yttrium, cerium, lanthanum and other rare-earth elements (REEs), which makes this FCH technology increasingly interesting for the recycling industry, especially from the perspective of the EU Member States, due to the heavy dependency on REE imports [14].

Within the Fuel Cells and Hydrogen Joint Undertaking, recommendations and guidelines to carry out life-cycle assessments (LCAs) of FCH technologies were published by the FC-HyGuide project [15]. As outlined in [16], FCH technologies are still difficult to assess with LCAs since the method has comprehensive data requirements and scarce available information on the materials and processes used by industry. The collection and validation of high-quality, life-cycle-inventory (LCI) data for each unit process is the most difficult and time-intensive aspect of developing the LCA [17]. After the materials are identified, several methodologies or approaches can be used to assess the criticality of these materials. The materials must be evaluated with a multi-criteria tool, due to the different impacts on the environment, human health, the economy, etc. [18]. In the past decade, the strategies proposed by National Research Council [19] and the Raw Materials Initiative [20] have accelerated the development of methods for assessing the criticality of raw materials. Nevertheless, assessments of critical materials are still at an early stage and according to [21], the evaluation methodologies can be further improved and more sectors and regions need critical materials' studies.

There are several reports and studies where various approaches to evaluating material criticality are proposed and/or assessed. In report [22], the criticality assessment of various metals was based on three criteria: (1) demand growth, (2) supply risk, and (3) recycling restrictions. Various aspects of material criticality and possible solution pathways to mitigate it are presented in a report [23]. The criticality of materials important for cleanenergy technologies was assessed in [24] and was based on two dimensions: importance to clean energy and supply risk. A supply-risk index for elements or element groups that are of economic value was determined by a ranking system based on four criteria in a report from 2011, which was updated in 2013 and ultimately in 2015 where seven criteria were used [25]. The report [26] implemented a repeatable method for identifying strategic and critical materials essential to the defence, technology and energy sectors, and proposes various scenarios to mitigate their supply-chain risk. The report [27] summarizes the results of a screening methodology where a two-stage approach was used. The first stage involves an indicator-based, early-warning screening that aims to identify a subset of the studied minerals as "potentially critical." The second stage utilizes the output of the early-warning screening to prioritize the potentially critical minerals for further in-depth analysis to understand the specific factors leading to their identification and determine which of them represent a significant risk to U.S. economic and national-security interests. In the European Union a list of critical raw materials was first published in 2011 and the European Commission is committed to updating the list at least every 3 years to reflect production, market and technological developments [28]. The methodology used to assess criticality [29] has a combination of two assessment components: economic importance and supply risk (poor governance). Compound indicators are used for each of these two assessment components; therefore, each takes multiple factors into account. The 
revised methodology was published in 2017 [30] and the latest list in 2020 [31] includes 30 critical raw materials. Following these reports, several scientific papers researched the methodologies used in material-criticality assessment. Some of them studied and compared the existing methodologies described above to obtain new insights into the assessment of material criticality [32,33], while some of them propose adaptations to the existing methodologies. In study [34], a methodology was presented and discussed that took account of three dimensions: supply risk, environmental implications, and vulnerability to supply restriction. In another study [35], an indicator is added to the EU criticality methodology, i.e., the international transformation of materials. Aspects of the EU criticality methodology, used to assemble the 2011 and 2014 material-criticality lists, were discussed in [36]. Specific elements that could be adapted were highlighted and their novelty and/or potential outcomes were presented. These guidelines were implemented in the next update of the methodology in 2017. A new methodology was proposed in study [37], where a dynamic material-flow model was integrated with a LCA, which created the first step towards a dynamic criticality assessment. Study [38] presented a new methodology, called SCARCE, which enhances existing criticality assessments by considering, next to availability and vulnerability, also social and environmental aspects.

As discussed above, and pointed out in [39], most criticality studies follow an approach analogous to a classic risk assessment, a method first introduced by [19]. They use the main matrix of a potential risk (e.g., supply risk and all the subcategories that should be considered) against vulnerability, i.e., the importance of a raw material for a specific area. In addition, in a research paper [39], the results of a survey on the "Awareness on use of "critical raw materials' in education and research", revealed that $47 \%$ of the surveyed researchers take into account the future availability of materials used in their research projects. However, only $33 \%$ of the surveyed researchers knew the origins of the used materials, which is an important factor when assessing any future supply risk. In contrast, $58 \%$ stated that they consider the price development of the materials. In cases where additional comments were given, the respondents stated that the toxicity, price and availability of the materials are the key factors in the search for new materials and that the substitution of critical or expensive materials by others is important. Since the price of a material is a dynamic and (to some extent) unpredictable parameter, it can only be assessed as a snapshot in time. However, as concluded from the survey in [39], it is an important factor when it comes to the selection of materials. It was also noted in [35] that in nearly all of the reviewed studies, the classification of materials according to their value (price) is absent.

There are also relatively few papers concerning the hazardousness and/or toxicity of raw materials. In the paper [40], a toxicological assessment compilation of selected raw materials (including platinum and precious metals) is presented, but is focused on acceptable amounts per daily intake, because the study is intended for homeopathic medicinal products. An empirical relationship between the score in a hazard-ranking system, used by the U.S. Environmental Protection Agency, and the primary energy intensity was discovered in [41]. As the primary energy intensity of a material increases, the hazard-ranking score of the land contaminated by hazardous waste (Superfund site) decreases. When coupled with material-price information, this relationship explains why less-energy-intensive and less-expensive materials are found with greater frequency and concentration at Superfund sites, despite their high toxicity; their recovery is not efficient from the energy or economic standpoints. The Priority List of Hazardous Substances [42] includes substances that have been assessed as being of the greatest public-health concern to people at or near the Superfund sites. Their frequency, toxicity, and potential for human exposure are the three criteria that contribute to the overall ranking of a substance on this list. Assessed only in terms of toxicity (which is divided into six categories), palladium is ranked in the second and platinum in the third category, which suggests that PGMs are relatively toxic. Silver is ranked in the fourth category, while gold and various REEs are ranked in the fifth and sixth categories (low to non-toxic). One of major issues remains the global harmonization 
of the classification and labelling of chemicals and materials. According to a study [43], the first steps were made back in 2009, when discussions to consider the development of a Globally Harmonised System of Classification and Labelling of Chemicals (GHS) was initiated by the United Nations. The study concluded that after 10 years there is still no concrete decision on this matter. Some countries have developed their own lists of classified chemicals; however, the study demonstrates that there is some discrepancy in the classification results for carcinogen, mutagen or reproductive toxicants among the selected countries (i.e., EU, Malaysia, Japan and New Zealand). An overview of the EU's regulation on the Registration, Evaluation, Authorisation and Restriction of Chemicals (REACH) and the requirements for the chemical registration of metals were presented for the case of aluminium compounds in Ref. [44]. Also, some of the issues and challenges in evaluating the potential human-health risks associated with metals were highlighted.

In a broader sense, hazardousness and / or toxicity is addressed using different environmental indicators. The study [34] added environmental implications as a third component to the methodology proposed in [19]. This approach was used in [45], where the substitution potential for 62 different metals in all their major uses and the performance of the substitutes in those applications were studied. It was shown that there was not even one example of the 62 metals where an exemplary substitute was available, i.e., for the REEs and PGMs, the best substitute is generally a metal from the same group, and this with basically the same supply risk as the original metal. The same methodology as in [34] was used in a study [46] where REEs were assessed on the global and national levels (USA and China). Interestingly, the analysis indicated a lower criticality for REEs over the longer term than for a number of other industrial metals. In [38] a new methodology was used that was aimed at enhancing the assessment of critical resource use at the country level (a case study of Germany) by considering all three sustainability dimensions (economic, social and environmental). Forty different metals were compared, and at the top of this list with the highest environmental impacts are gold, tungsten, platinum and silver.

According to the European Commission's report [47], the EoL recycling input rates are still very low for PGMs and REEs, which are on average $11 \%$ and $6 \%$, respectively. This means that even for materials for which overall recycling rates are relatively high (e.g., the recycling rates for PGMs are up to 95\% for industrial catalysts and 50-60\% for automotive catalysts), recycling's contribution to meeting the demand for materials is relatively low. This is because demand is higher than the level that can be met by current recycling capacities. That is why there is a strong and growing interest in the development of novel, more productive and environmentally friendly recycling technologies [48,49], [50]. Also, the EU is following its Raw Materials Initiative [20] by funding various research projects that are concerned with increasing the supply or reducing the demand for at least one critical material [51]. Recently, this initiative was supported by two Horizon 2020 calls that aim to develop eco-design guidelines for $\mathrm{FCH}$ products [52] and the validation of existing and novel recycling technologies for key FCH products [53]. The second project is especially industrially oriented and, among other things, will try to answer the question of whether recycled materials can achieve the properties of virgin materials and can be used to replace them completely.

The purpose and novelty of this paper is to show how existing methodologies can be used and aggregated together to obtain relevant data on materials that are the most used in FCH technologies. The focus is on four different FCH technologies (AWE, PEMWE, PEMFC and SOFC) that are the most widely used and were the focus of the research project HyTechCycling [54] that aimed to deliver the reference documentation and studies on both conventional and novel EoL technologies and strategies applicable to FCH technologies [55]. One of the contributions presented in this paper is an assessment of the environmental impacts of FCH materials with an innovative methodological approach. This is new approach in which three criteria for evaluating materials (hazardousness, EU criticality method and price) are combined into a single score for a preliminary evaluation of $\mathrm{FCH}$ materials. In addition, an inventory list of most common materials in $\mathrm{FCH}$ technologies 
was assembled and was assessed using the LCA methodology. The LCA analysis was conducted only for the manufacturing phase (cradle-to-gate analysis) and the results were compared/validated with the new single-score FCH material inventory list. Furthermore, this approach shows a quicker identification of the most influential or critical materials that substantially increase the environmental impact of the considered technologies and might hinder their wider commercialisation. The focus was on an assessment of critical materials, where environmental impacts are also evaluated in accordance with the improvements over the last decade (lower catalyst loadings, substitute materials used, etc.). The results are presented together for all the considered materials, but also separately for each observed technology, which should be of great interest to the FCH industry and policymakers.

\section{Materials and Methods}

The four FCH technologies considered in the EU HyTechCycling project were broken down into the core components to identify the most used materials in these technologies. Although balance-of-plant (BoP) components are not the primary focus of this study, they were included in the analysis because they also include valuable materials such as PGMs, REEs, precious metals, etc. The strategy for identifying critical materials is shown in Figure 1. The first goal was to screen the most used materials in $\mathrm{FCH}$ technologies and prepare the LCI lists. These lists were evaluated by using our own methodological approach, with the aim to already identify the potentially critical materials. The results of this preliminary analysis were the cornerstone of the HyTechCycling project and were published as part of the project's deliverables [56]. Furthermore, the assembled lists of these materials were analysed in greater detail using the LCA methodology. This also made it possible to compare and validate the results of the preliminary analysis with respect to the in-depth LCA analysis and detect the potential outliers in both approaches.
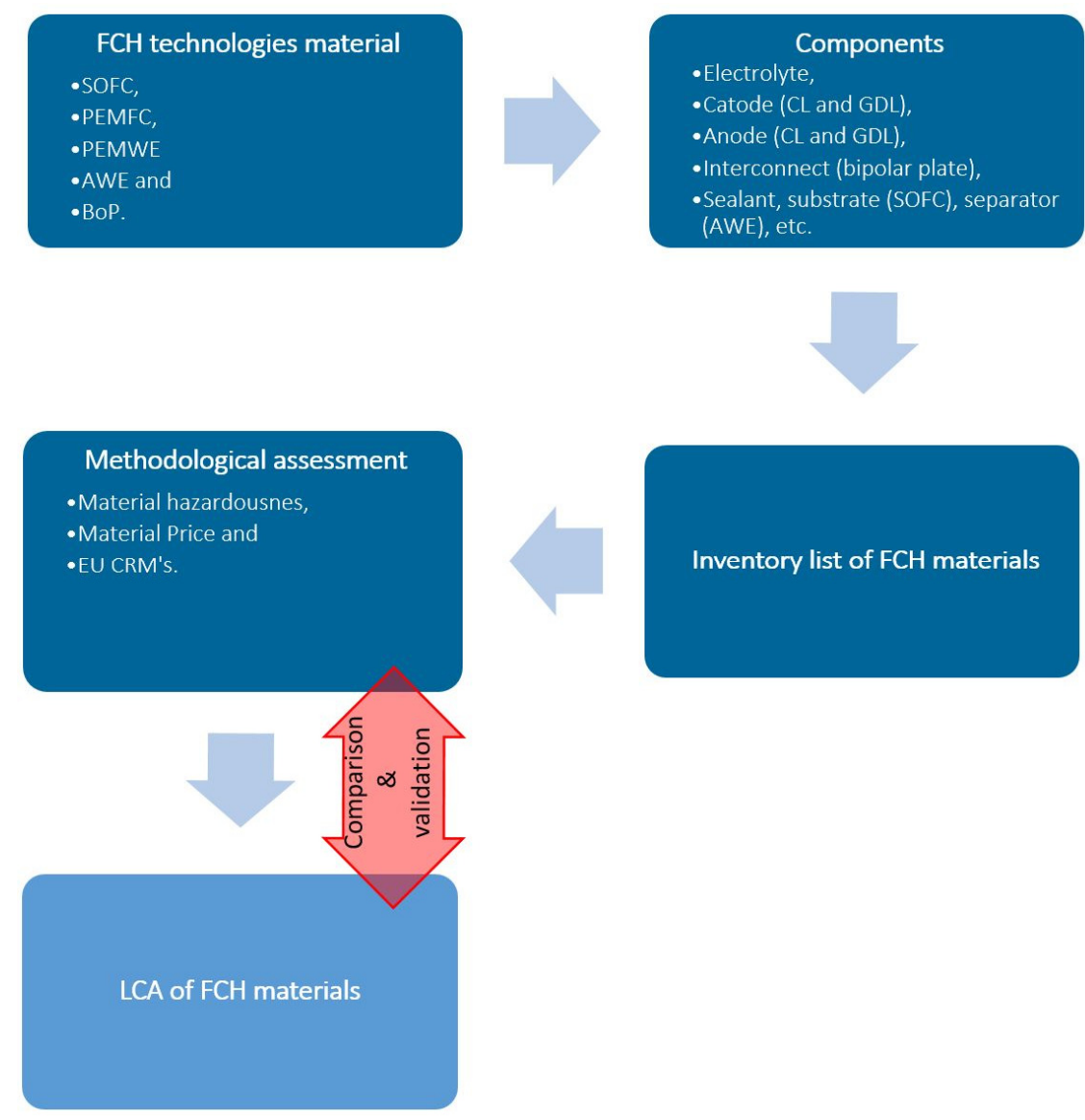

Figure 1. Strategy for identifying and validating critical materials in $\mathrm{FCH}$ technologies. 


\subsection{Methodological Assessment}

In the case of fuel-cell systems, the focus in this research is on SOFCs and PEMFCs. These two types of fuel-cell stacks were broken down into their main components: electrolyte, anode, cathode, catalyst layer, GDL, interconnect and sealants. On the other hand, water electrolyses based on AWEs and PEMWEs are the key electrochemical hydrogenproduction technologies considered in this study. These two types of electrolyser stacks were broken down into their main components in the same manner as the fuel-cell stacks. Based on the materials comprising the main components of the considered $\mathrm{FCH}$ technologies, the lists of materials were drawn up. The critical materials within these four FCH technologies were identified according to three criteria: hazardousness, price and EU criticality methodology.

A hazardous material (the first assessment criterion) is defined as a substance that has an adverse effect on humans, animals or the environment. To determine the hazardousness of materials in FCH technologies the Globally Harmonised System of Classification and Labelling of Chemicals (GHS) was adopted as a standard. As explained in [57], the GHS provides a harmonised basis for globally uniform, physical, environmental, and healthand-safety information about hazardous chemical substances and mixtures. It sets out the criteria for a classification of the chemicals for the physical-chemical, health and environmental hazards of chemical substances and mixtures and sets out standardised hazard information to facilitate the global trade of chemicals. The GHS has been implemented in the EU by Regulation (EC) No 1272/2008 on the classification, labelling and packaging of substances and mixtures (the 'CLP Regulation'). In line with the GHS standard, CLP allows for the identification of hazardous chemicals and the communication of these hazards to users through labelling. The EU works closely with the European Chemicals Agency (ECHA) and has established a European regulation REACH [58] where the main objective of ensuring a high level of protection for human health and the environment is established by shifting the responsibility from public authorities to industry with regards to assessing and managing the risks posed by chemicals and providing the appropriate safety information for their users. Based on a three-level classification of chemicals and materials in the ECHA database, the FCH materials were classified as low, medium or high in terms of hazardousness. The second assessment criterion is the price of the material, which was estimated based on the Asian Metal Market [59], London Metal Exchange [60], Elements and their compounds list [61]. The prices of some compounds and raw materials are volatile due to constantly changing demand and supply. That is why price as a criterion in our study is more related to material criticality because it also reflects the relationship between the demand (growth of the market for a particular material) and supply (production and recycling capabilities). Also, material prices undoubtedly influence the decision-making of the recycling industry, which has a direct effect on the environmental footprint of materials. After the price estimation, three categories of material price were defined: Low $(<5 \$ / \mathrm{kg})$, Medium (5-500 \$/ kg) and High (>500 \$/ kg). The third assessment criterion, which is closely connected with material scarcity, is the EU's criticality methodology [29,30], which is a combination of two assessment components: economic importance (EI) and supply risk (SR). The last assessment in 2020 [31] applies a revised version of the European Commission's criticality methodology, while ensures comparability with the previous methodology used in 2011, 2014 and 2017. The overall results of the fourth assessment are shown in Table 1 and Figure 2. The critical raw materials (CRMs) are marked with red dots and are located inside the criticality zone (SR threshold $\geq 1$ and EI threshold $\geq 2.8$ ). If an assessed material is in this zone, it is ranked as high in terms of EU criticality. The blue dots represent the non-CRMs; these materials were ranked as low for EU criticality. For the assessed materials that exceed only one threshold in the EU criticality methodology, we introduced a new level and ranked them as medium.

The novelty in this paper is the aggregation of the three evaluation criteria for a materials assessment of FCH technologies: hazardousness of material (1st criterion), estimated price of the material (2nd criterion) and EU's criticality assessment (3rd criterion). The 
assessment of the material's criticality is based on an evaluation and scoring of each of the three criteria-where High means 3 points, Medium, 1 point, and Low, 0 points. By summing the points of all the criteria, the materials are ranked into three categories using the scoring system shown in Table 2. A total score of 5 to 9 points means that the material is ranked as very critical; a total score from 2 to 4 points means that material is medium critical; and score from 0 and 1 represents low or non-critical materials According to the scoring presented in Table 2, we assessed the list of all possible materials used in the $\mathrm{FCH}$ technologies and BoP components.

Table 1. List of EU CRM's based on 2020 criticality assessment, [31].

\begin{tabular}{llll}
\hline $\mathbf{2 0 2 0}$ CRM's (30) & & & \\
\hline Antimony & Fluorspar & Magnesium & Silicon metal \\
Baryte & Gallium & Natural graphite & Tantalum \\
Bauxite & Germanium & Natural rubber & Titanium \\
Beryllium & Hafnium & Niobium & Vanadium \\
Bismuth & HREEs & PGMs & Tungsten \\
Borate & Indium & Phosphate rock & Strontium \\
Cobalt & Lithium & Phosphorus & \\
Coking coal & LREEs & Scandium & \\
\hline
\end{tabular}

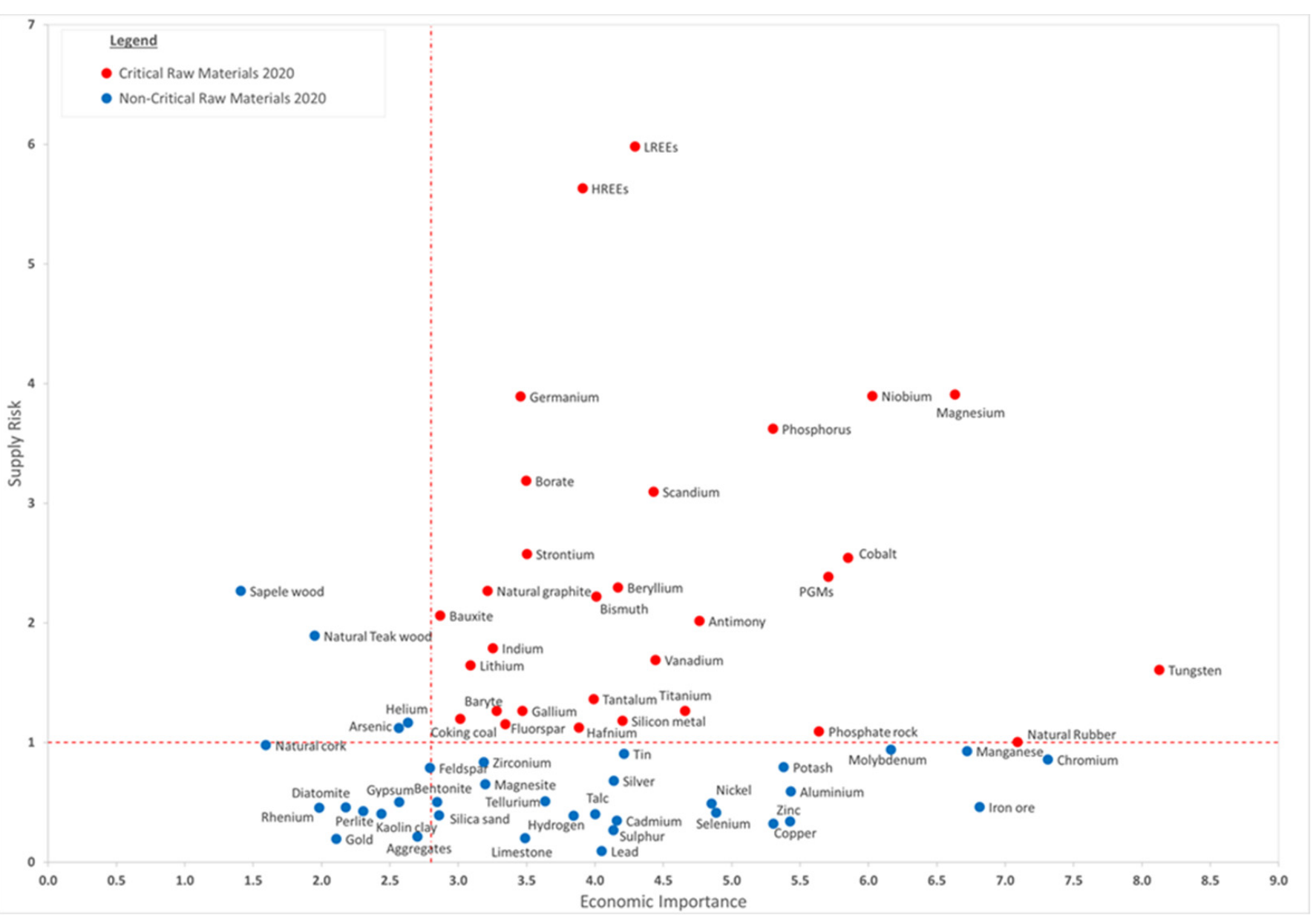

Figure 2. Economic importance and supply risk for the EU's 2020 criticality assessment, [31].

One of the advantages of the integration of FCH technologies in energy systems is their environmental performance, which is better than the environmental performance of conventional fossil-fuel-based technologies [62]. Currently, the environmental impact of 
FCH technologies comes mainly from the hydrogen production (the majority of hydrogen is still made from natural-gas steam reforming); but a very important segment that is not properly addressed yet is the production phase, where the production of materials (raw sources extraction, preparation, production) plays a significant role [63]. The environmental performance evaluated with the LCA approach can be misleading if the critical materials are not addressed properly. A study by an untrained LCA practitioner, or simply inattention, could neglect some of the critical materials involved in the $\mathrm{FCH}$ production phase due to the very low masses (e.g., in PEMFC or PEMWE systems, the PGMs' weight ratio can be as low as $0.01 \%$ of the total mass of the system [64]). To properly address the circular economy in the future, all important critical materials must be included in the LCA studies. To obtain a deeper understanding of the importance of materials - and based on that the preliminary assessment of criticality - we have used this innovative methodological approach where the environmental impacts of materials are evaluated by using three individual impact categories aggregated together to achieve the final score.

Table 2. Scoring system for assessing the criticality of materials.

\begin{tabular}{|c|c|c|c|c|}
\hline 1st Criteria & 2nd Criteria & 3rd Criteria & Score & Criticality \\
\hline High & High & High & 9 & \multirow{4}{*}{ High } \\
\hline High & High & Medium & 8 & \\
\hline High & High & Low & 6 & \\
\hline High & Medium & Medium & 5 & \\
\hline High & Medium & Low & 4 & \multirow{4}{*}{ Medium } \\
\hline High & Low & Low & 3 & \\
\hline Medium & Medium & Medium & 3 & \\
\hline Low & Medium & Medium & 2 & \\
\hline Low & Low & Medium & 1 & \multirow{2}{*}{ Low } \\
\hline Low & Low & Low & 0 & \\
\hline
\end{tabular}

\subsection{Life-Cycle Assessment Approach}

The Life Cycle Assessment includes four phases: (i) goal and scope, (ii) life-cycle inventory analysis (LCI), (iii) life-cycle impact assessment (LCIA), and (iv) interpretation of results. It was conducted according to the ISO standards 14040 [65], 14044 [66], and ILCD guidelines [67]. The provisions and suggestions given in the guidance document for performing a LCA on FCH technologies by [68], were also considered in the analysis. For this purpose, a specific calculation tool called Gabi software [69] was used. The first step in conducting the LCA was the identification of all the relevant materials in the observed FCH technologies, which is also one of the main outputs of this study. In addition to critical materials, other materials of interest were also assessed using a LCA. Secondary data from the generic databases were taken from the ecoinvent 3.6 [70] and the GaBi Professional database [71], or adopted from the EU H2020 project HyTechCycling. Since some of the materials are not available in generic databases (especially for SOFC technology) they were modelled according to the available research literature and/or chemical composition [72].

\subsubsection{Goal, Scope and Functional Unit}

The goal of this study is to analyse the production phase of materials that are most used in FCH systems to evaluate and compare their environmental impacts. Also, each FCH technology is evaluated separately to focus attention on the most critical materials within the technology and on the future steps that can be taken to reduce the environmental impact. The improvements to the FCH technologies over the last decade are commented on and address the materials with the largest environmental impacts, greatest scarcity or highest price with the purpose of elucidating the setbacks, advantages and/or potentials of these materials. The analysis was conducted from "the cradle to the gate", from harvesting the unprocessed resources to a material usable by the manufacturer of the FCH compo- 
nent. The functional unit for the LCA was a mass of $1 \mathrm{~g}$ of material used in the assessed FCH technologies.

\subsubsection{Life-Cycle Inventory Analysis}

The life-cycle inventory (LCI) was based on lists of materials obtained using the methodological approach described in Section 2.1. This implies that the processes needed to produce the core components (mixing of compounds, film casting, stamping/pressing, sintering, etc.) are not within the scope of this analysis. To successfully execute the LCA the materials must be available in the LCA databases or we must have all the data regarding the production process for a specific material. However, in some cases we are dealing with rather new materials; therefore, some of them are still not available in the LCA databases. If a material is missing in the database, it should be replaced by a comparable material that exhibits similar properties or the LCI for that material must be additionally defined.

\subsubsection{Life-Cycle Impact-Assessment Method Used}

The CML2001 and EF3.0 Life Cycle Impact Assessment (LCIA) methodologies were used to evaluate the results. The CML2001 methodology is a very reliable and commonly used LCIA methodology in LCA research papers. Since EF3.0 might not be robust and proficient enough, and there is also a lack of application experience with widely used LCI databases, the CML2001 methodology-which was used in all the LCA analyses within the HyTechCycling project, [73] — was additionally used to compare and verify the results. However, the European Commission has proposed the PEF (Product Environmental Footprint) and the OEF (Organisation Environmental Footprint) as a common way of measuring environmental performance [74]. The overarching purpose of PEF information is to make it possible to reduce the environmental impacts of goods and services, taking into account supply-chain activities (from the extraction of raw materials, through production and use and on to final waste management) [75]. For this reason, we additionally used the EF3.0 methodology - which is currently undergoing a transition phase in the development of EF characterization - that is strongly supported and supervised by the Joint Research Centre. The EF3.0 methodology includes more environmental impact indicators that give additional information regarding the environmental impacts of the production processes of materials.

\subsubsection{Interpretation of the Results}

To obtain a detailed interpretation of the environmental impact of the materials for each observed FCH technology, the LCA model was set up separately for all the materials occurring in the production phase of the $\mathrm{FCH}$ technology and separately for the BoP components. The environmental impacts of the production phase of the materials were calculated and assessed using the EF3.0 and CML2001 LCIA methods. Both methods were used in the interpretation of the results to obtain a comparison of the environmental impacts. Also, parallels are drawn with the methodological approach presented above to see if the environmental impact indicators from the LCA correlate with the methodological approach (Section 2.1).

\section{Results}

As a first output the lists of current materials used in the production phase of each observed technology are presented separately in tables. The aggregated list of all the materials in the considered FCH technologies is also presented in a table, where the methodological approach is used to evaluate the materials with a single indicator, which is a score obtained from the three criteria (a combination of hazardousness, price and EU criticality). To compare the environmental impacts obtained from the methodological assessment with the environmental impact indicators, the LCI was constructed and the production processes of the materials were identified for each material. The LCA results for the materials' production are commented on in the last section of the results. 


\subsection{Inventory of Materials in FCH Technologies and Methodological Assessment}

All the relevant materials are presented for each FCH technology and for the BoP components. The LCIs of the processes used in the LCA models are taken from the ecoinvent 3.6, GaBi Professional, Gabi extension databases and additional data on demand, [76]. Some processes were modelled according to a life-cycle inventory from the literature or research, a few were substituted according to suggestions from the literature or research and several were modelled according to the chemical composition of the materials. In this last approach we modelled the materials with the appropriate amounts of raw materials according to their chemical composition, but due to a lack of data we neglected or cut-off the auxiliary materials (such as solvents, etc.) and the energy required to produce the material. With this we underestimated the environmental impacts of the material's production, but we were able to assess the environmental impacts of almost all the materials used in the FCH technologies and compared them with the methodological assessment. From Tables 3-6 all the materials that could be used (by different manufacturers) in the four observed technologies are listed and linked with secondary or primary databases used in the LCA approach. The material lists are not presented with the unit of mass because the mass (and choice of materials) depend on the components used by the manufacturer and also on the size of the system. This means the exact masses of materials is proprietary information of each manufacturer and consequently not available to the general public.

SOFC materials mainly consist of REEs, which makes this FCH technology critical from the perspective of the EU Member States due to the heavy dependence on REE imports [14]. The materials are classified as relatively costly and low in toxicity, except for nickel and cobalt, which are classified as carcinogens. For the SOFC technology, all possible materials used in the production process are presented in Table 3.

Most materials used to build the components for SOFC technology are composites. This implies that these materials are already half-products, where various resources and energy were needed to produce them. Since the materials for SOFC components are still under development-and so their compositions can vary a lot from producer to producerthis makes it difficult to implement them into the LCI databases. Due to this lack of information in the LCI databases some of the materials are modelled based on available literature. In cases where no data are available, the composite materials are modelled solely by the weight ratios of the materials comprising the composite. We are aware that this only gives a rough estimate of the environmental impacts, because there are several production processes and waste streams that are left out using this approach. However, this clearly demonstrates that a combined effort by industry, research institutions and policymakers must be made to improve the LCI databases with reliable and up-to-date data.

Table 3. List of materials in SOFCs and the available inventory.

\begin{tabular}{|c|c|c|c|}
\hline & Component & Material & Processes Used in SOFC LCA Model \\
\hline \multirow{10}{*}{ SOFC } & \multirow{3}{*}{ Electrolyte } & Yttria-stabilised zirconia (YSZ) & Yttria-stabilised zirconia (YSZ) ${ }^{1}$ \\
\hline & & Cerium gadolinium oxide & Cerium(IV) oxide-gadolinium doped ${ }^{2}$ \\
\hline & & Cerium samarium oxide & Cerium(IV) oxide-samarium doped ${ }^{2}$ \\
\hline & \multirow[t]{2}{*}{ Anode } & Nickel-based oxide doped with YSZ & No Available Data \\
\hline & & 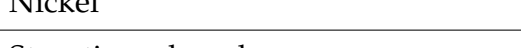 & 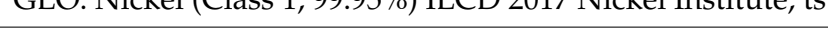 \\
\hline & \multirow{2}{*}{ Cathode } & Strontium-doped & RER: Lanthanum strontium manganite (LSM) ${ }^{2}$ \\
\hline & & Lanthanum strontium cobalt ferrite & Lanthanum strontium cobalt ferrite (LCSF) ${ }^{2}$ \\
\hline & Interconnect & Doped lanthanum chromate & EU28: Lanthanum chromate production (estimation), ts \\
\hline & \multirow[b]{2}{*}{ Sealant } & Glass-ceramic & EU28: Glass ceramic production, ts \\
\hline & & Phyllosilicates (Vermiculite) & GLO: market for vermiculite ecoinvent 3.6 \\
\hline
\end{tabular}

${ }^{1}$ modelled according to LCI from the literature, [72], ${ }^{2}$ modelled according to chemical composition-estimation. 
PEMFC materials are mainly low-to-medium in cost, with the exception of PGMs. Most of the materials used in this FCH technology are classified as non-hazardous, with the exception of the PGMs and PBI membranes doped with $\mathrm{H}_{3} \mathrm{PO}_{4}$, which are only used in high-temperature PEMFCs. Other critical materials in PEMFCs are PFSA, which is the most common material for low-temperature electrolyte membranes, followed by sulfonated PEEK and Teflon, which are both rated as medium-to-high according to the EU's criticality method. For the PEMFC technology, all possible materials used in the production process are presented in Table 4.

Table 4. List of materials in PEMFCs and the available inventory.

\begin{tabular}{|c|c|c|c|}
\hline & Component & Material & Process in LCA Database \\
\hline \multirow{5}{*}{ PEMFC } & Electrolyte & $\begin{array}{l}\text { Perfluorosulphonic acid (PFSA-Nafion) } \\
\text { Sulfonated polyether ether ketone (s-PEEK) } \\
\text { Polybenzimidazole (PBI) doped with } \\
\mathrm{H}_{3} \mathrm{PO}_{4} \text { (HT-PEM) }\end{array}$ & $\begin{array}{l}\text { CA: Nafion-for use in fuel cell ts } \\
\text { DE: Polyetherether ketone granulate (PEEK) ts } \\
\text { RER: polybenzimidazole (PBI) }{ }^{1}\end{array}$ \\
\hline & GDL & $\begin{array}{l}\text { Carbon fibres } \\
\text { Metallic mesh (steel product) }\end{array}$ & $\begin{array}{l}\text { EU-28: Polyacrylonitrile Fibres (PAN) ts }{ }^{2} \\
\text { DE: EAF Steel billet/Slab/Bloom ts }<\text { p-agg }>\end{array}$ \\
\hline & Catalyst layer & $\begin{array}{l}\text { Platinum and Pt-alloys } \\
\text { PTFE-Teflon (hydrophobic agent) } \\
\text { Carbon black (catalyst support) }\end{array}$ & $\begin{array}{l}\text { GLO: Platinum mix ts } \\
\text { DE: Polytetrafluoroethylene granulate (PTFE) Mix ts } \\
\text { DE: Carbon black (furnace black; general purpose) ts }\end{array}$ \\
\hline & Interconnect & $\begin{array}{l}\text { Graphite } \\
\text { Stainless steel }\end{array}$ & $\begin{array}{l}\text { RER: graphite production ecoinvent } 3.6 \\
\text { DE: Stainless-steel slab (X6CrNi17) ts }<\text { p-agg }>\end{array}$ \\
\hline & Sealant & Elastomer (Silicone, Viton ${ }^{\circledR}$, EPDM) & $\begin{array}{l}\text { DE: Polythetraflouroetylene granulate (PTFE) Mix ts } \\
\text { EU-28: Silicone sealing compound ts } \\
\text { DE: Styrene-butadiene rubber (S-SBR) } \operatorname{mix}^{3} \\
\text { EU-28: EPDM roofing membranes ts }\end{array}$ \\
\hline
\end{tabular}

\footnotetext{
${ }^{1}$ modelled according to chemical composition—estimation, ${ }^{2}$ substitution for carbon fibres-PAN is a precursor, ${ }^{3}$ substitution for synthetic
} rubbers, e.g., Viton ${ }^{\circledR}$.

Table 5. List of materials in PEMWEs and the available inventory.

\begin{tabular}{|c|c|c|c|}
\hline & Component & Material & Process in LCA Database \\
\hline \multirow{14}{*}{ PEMWE } & \multirow{2}{*}{ Electrolyte } & \multirow{2}{*}{$\begin{array}{l}\text { Perfluorosulphonic acid (PFSA-Nafion) } \\
\text { Sulfonated polyether ether ketone } \\
\text { (s-PEEK) }\end{array}$} & CA: Nafion-for use in fuel cell ts \\
\hline & & & DE: Polyetherether ketone granulate (PEEK) ts \\
\hline & \multirow{2}{*}{ GDL } & \multirow{2}{*}{$\begin{array}{l}\text { Carbon fibres (only cathode side) } \\
\text { Titanium or Ti-alloys }\end{array}$} & EU-28: Polyacrylonitrile Fibres (PAN) ts ${ }^{1}$ \\
\hline & & & GLO: titanium production, primary ecoinvent 3.6 \\
\hline & \multirow{6}{*}{ Catalyst layer } & \multirow{6}{*}{$\begin{array}{l}\text { Platinum and Pt-alloys (cathode side) } \\
\text { Palladium and Pd-alloys (cathode side) } \\
\text { Carbon black (cathode side } \\
\text { catalyst support) } \\
\text { Iridium and Ir-alloys (anode side) } \\
\text { Ruthenium and Ru-alloys (anode side) } \\
\text { Titanium dioxide (anode side } \\
\text { catalyst support) }\end{array}$} & GLO: Platinum mix ts \\
\hline & & & GLO: Palladium mix ts \\
\hline & & & DE: Carbon black (furnace black; general purpose) ts \\
\hline & & & No Available Data ${ }^{2}$ \\
\hline & & & ZA: Ruthenium ts \\
\hline & & & RER: market for titanium dioxide ecoinvent 3.6 \\
\hline & \multirow{2}{*}{ Interconnect } & Titanium or Ti-alloys & GLO: titanium production, primary ecoinvent 3.6 \\
\hline & & Stainless steel & DE: Stainless-steel slab (X6CrNi17) ts <p-agg > \\
\hline & \multirow[t]{2}{*}{ Sealant } & Elastomer (Silicone, Viton ${ }^{\circledR}$, EPDM) & $\begin{array}{l}\text { EU-28: Silicone sealing compound (EN15804 A1-A3) ts } \\
\text { DE: Styrene-butadiene rubber (S-SBR) } \mathrm{mix}^{3} \\
\text { EU-28: EPDM roofing membranes ts }\end{array}$ \\
\hline & & Thermoplastic (PTFE) & DE: Polytetrafluoroethylene granulate (PTFE) Mix ts \\
\hline
\end{tabular}

${ }^{1}$ substitution for carbon fibres-PAN is a precursor, ${ }^{2}$ instead of iridium ruthenium could be used as a substitute in LCA modelling, ${ }^{3}$ substitution for synthetic rubbers, e.g., Viton ${ }^{\circledR}$. 
PEMWE materials are similar to those of the PEMFC. The oxygen-evolution-reaction (OER) and hydrogen-evolution-reaction (HER) catalysts are based on PGMs, which means that these materials are also classified as critical and high cost. The materials are mainly non-hazardous, with the exception of the PGMs used for catalysts. For the PEMWE technology, all possible materials used in the production process are presented in Table 5. 
Table 6. List of materials in AWEs and the available inventory.

\begin{tabular}{|c|c|c|c|}
\hline & Component & Material & Process in LCA Database \\
\hline \multirow{10}{*}{ AWE } & \multirow{2}{*}{ Electrolyte } & Potassium hydroxide & RER: potassium hydroxide production ecoinvent 3.6 \\
\hline & & Sodium hydroxide & $\begin{array}{l}\text { DE: Sodium hydroxide (from chlorine-alkali } \\
\text { electrolysis, diaphragm) ts }\end{array}$ \\
\hline & Anode & Nickel & $\begin{array}{l}\text { GLO: Nickel (Class 1, 99.95\%) ILCD } 2017 \text { Nickel } \\
\text { Institute, ts }\end{array}$ \\
\hline & Cathode & Nickel & $\begin{array}{l}\text { GLO: Nickel (Class 1, 99.95\%) ILCD } 2017 \text { Nickel } \\
\text { Institute, ts }\end{array}$ \\
\hline & Interconnect & Nickel & $\begin{array}{l}\text { GLO: Nickel (Class 1, 99.95\%) ILCD } 2017 \text { Nickel } \\
\text { Institute, ts }\end{array}$ \\
\hline & & Stainless steel & DE: Stainless-steel slab (X6CrNi17) ts <p-agg> \\
\hline & & Thermoplastic (PTFE) & $\begin{array}{l}\text { DE: Polytetrafluoroethylene granulate (PTFE) Mix ts } \\
\text { EU-28: Silicone sealing compound (EN15804 A1-A3) ts }\end{array}$ \\
\hline & Sealant & Elastomer (Silicone, Viton ${ }^{\circledR}$, EPDM) & $\begin{array}{l}\text { DE: Styrene-butadiene rubber (S-SBR) mix }{ }^{1} \\
\text { EU-28: EPDM roofing membranes ts }\end{array}$ \\
\hline & & Asbestos (old AWE) & GLO: asbestos production, crysotile type ecoinvent 3.6 \\
\hline & $\begin{array}{l}\text { Diaphragm } \\
\text { (membrane) }\end{array}$ & $\begin{array}{l}\text { Composite of polysulfone and } \mathrm{ZrO}_{2} \\
\left(\text { (Zirfone }^{\circledR}\right)\end{array}$ & Polysulfone Composite-Zirfone $<\mathrm{LC}>^{2}$ \\
\hline
\end{tabular}

${ }^{1}$ substitution for synthetic rubbers, e.g., Viton ${ }^{\circledR},{ }^{2}$ modelled according to chemical composition-estimation.

AWE materials are mainly low cost, with the exception of both the anode and cathode catalysts, which are also classified as critical by the EU. This FCH technology is also classified as rather hazardous, since an alkaline electrolyte in liquid form is used (i.e., $\mathrm{KOH}$ or $\mathrm{NaOH}$ ). In addition, the Ni-based catalysts and asbestos diaphragms used in older types of AWE are classified as carcinogens. For the AWE technology, all possible materials used in the production process are presented in Table 6.

The main materials used in BoP components are shown in Table 7, with the processes used from the LCA database. In BoP the main materials of interest are precious metals (e.g., gold and silver) typically used in printed wire boards (PWBs) and materials used in batteries, e.g., lead, tin and lithium $\left(\mathrm{LiFePO}_{4}\right)$, which are classified as toxic to human health or the environment. Silicon products (silicone rubber, microporous insulation, etc.) are classified as critical due to the high criticality of silicon metal in the EU as the main raw material for production.

The materials most used in $\mathrm{FCH}$ technologies and $\mathrm{BoP}$ are aggregated and presented in Table 8, which is the list of materials assessed according to the methodology described in Section 2.1. Table 8 shows the assessment results for all the materials according to each of the three criteria and in the last column under a new assessment of the overall rating of the material's criticality. Based on the new material-evaluation methodology, there are a total of 16 materials in the FCH technologies that have a high criticality, 12 materials with a medium criticality, and the rest are of low criticality. For a more descriptive presentation, the materials are color-coded and arranged from very critical materials (redHigh criticality) to the least critical materials (green-Low criticality). Some materials are used in more than one FCH technology; this can be seen in the third column of Table 8.

Among the most critical materials (coloured red), most of the materials are used in SOFC technology (11 out of 16). Moreover, 4 out of 16 materials that are ranked high in criticality are used in PEMWE technology, 2 out of 16 are used in PEMFC technology, and only one in AWE, while 3 out of 16 critical materials are commonly used in BoP components. 
Table 7. List of BoP components and materials.

\begin{tabular}{|c|c|c|}
\hline Components & Materials & Process in LCA database \\
\hline \multirow{2}{*}{ Main BoP components } & Metals & $\begin{array}{l}\text { GLO: Aluminium ingot mix IAI (2010) IAI, ts } \\
\text { DE: EAF Steel billet/Slab/Bloom ts }<\mathrm{p} \text {-agg }> \\
\text { DE: Stainless-steel slab (X6CrNi17) ts }<\mathrm{p} \text {-agg }> \\
\text { GLO: Copper mix ( } 99,999 \% \text { from electrolysis), ts } \\
\text { GLO: market for steel, chromium steel } 18 / 8 \text { ecoinvent } 3.6\end{array}$ \\
\hline & $\begin{array}{l}\text { Plastics } \\
\text { Elastomers } \\
\text { Thermoplastic } \\
\text { Polymers }\end{array}$ & $\begin{array}{l}\text { EU-28 Polypropylene, PP, granulate agg, ts } \\
\text { EU28: Polyethylene, HDPE, granulate, ts } \\
\text { EU-28: Silicone sealing compound (EN15804 A1-A3) ts } \\
\text { DE: Polytetrafluoroethylene granulate (PTFE) Mix ts } \\
\text { EU-28: EPDM roofing membranes ts }\end{array}$ \\
\hline \multirow{3}{*}{ Ancillary BoP components } & Metals & $\begin{array}{l}\text { GLO: Aluminium ingot mix IAI (2010) IAI, ts } \\
\text { GLO: market for steel, chromium steel } 18 / 8 \text { ecoinvent } 3.6 \\
\text { DE: Stainless-steel slab (X6CrNi17) ts <p-agg }> \\
\text { GLO: Copper mix ( } 99,999 \% \text { from electrolysis), ts } \\
\text { DE: EAF Steel billet/Slab/Bloom ts }<\text { p-agg }>\end{array}$ \\
\hline & $\begin{array}{l}\text { Plastics } \\
\text { Elastomers } \\
\text { Thermoplastic } \\
\text { Polymers }\end{array}$ & $\begin{array}{l}\text { EU-28 Polypropylene, PP, granulate agg, ts } \\
\text { EU28: Polyethylene, HDPE, granulate, ts } \\
\text { EU-28: Silicone sealing compound (EN15804 A1-A3) ts } \\
\text { EU-28: EPDM roofing membranes ts } \\
\text { DE: Polytetrafluoroethylene granulate (PTFE) Mix ts }\end{array}$ \\
\hline & Precious metals & $\begin{array}{l}\text { GLO: Silver mix ts } \\
\text { GLO: Gold (primary) ts } \\
\text { GLO: Palladium mix ts }\end{array}$ \\
\hline Other BoP components & Other & $\begin{array}{l}\text { GLO: market for tin ecoinvent } 3.6 \\
\text { DE: Lead }(99,995 \%) \text { ts } \\
\text { DE: Lithium Iron Phosphate/Carbon Composition } \\
\text { (cathode active material), ts } \\
\text { EU-28: Glass wool ts } \\
\text { EU-28: Silicone sealing compound (EN15804 A1-A3) ts }\end{array}$ \\
\hline
\end{tabular}

Table 8. List of commonly used FCH and BoP materials with results of the new methodological assessment.

\begin{tabular}{|c|c|c|c|c|c|c|}
\hline \multirow{2}{*}{ Material } & \multirow{2}{*}{ Component } & \multirow{2}{*}{ Technology } & \multicolumn{3}{|c|}{ Methodological Assessment } & \multirow{2}{*}{$\begin{array}{c}\text { New } \\
\text { Assessment }\end{array}$} \\
\hline & & & Hazardous & Price & EU Criticality & \\
\hline $\begin{array}{c}\text { Cerium gadolinium } \\
\text { oxide }\end{array}$ & Electrolyte & SOFC & High & Medium & High & High \\
\hline $\begin{array}{l}\text { Cerium samarium } \\
\text { oxide }\end{array}$ & Electrolyte & SOFC & High & Medium & High & High \\
\hline Copper & PWB's, Cables & $\mathrm{BoP}$ & High & Medium & Medium & High \\
\hline $\begin{array}{l}\text { Doped Lanthanum } \\
\text { chromate }\end{array}$ & Interconnect & SOFC & Medium & Medium & High & High \\
\hline $\begin{array}{c}\text { Iridium } \\
\text { Lanthanum }\end{array}$ & Catalyst & PEMWE & Low & High & High & High \\
\hline $\begin{array}{c}\text { Strontium Cobalt } \\
\text { Ferrite }\end{array}$ & Cathode & SOFC & Low-Medium & Medium & High & High \\
\hline Nickel & $\begin{array}{l}\text { Catalyst, } \\
\text { Electrode }\end{array}$ & SOFC, AWE & High & Medium & Medium & High \\
\hline $\begin{array}{l}\text { Nickel-based oxide } \\
\text { doped with YSZ }\end{array}$ & Anode & SOFC & Medium-High & Medium & High & High \\
\hline Palladium & $\begin{array}{c}\text { Catalyst, } \\
\text { Interconnect, } \\
\text { Ancillary BoP }\end{array}$ & $\begin{array}{l}\text { SOFC, PEMWE, } \\
\text { BoP }\end{array}$ & Low-Medium & High & High & High \\
\hline Platinum & Catalyst & $\begin{array}{l}\text { PEMFC, } \\
\text { PEMWE }\end{array}$ & Low & High & High & High \\
\hline
\end{tabular}


Table 8. Cont

\begin{tabular}{|c|c|c|c|c|c|c|}
\hline \multirow{2}{*}{ Material } & \multirow{2}{*}{ Component } & \multirow{2}{*}{ Technology } & \multicolumn{3}{|c|}{ Methodological Assessment } & \multirow{2}{*}{$\begin{array}{c}\text { New } \\
\text { Assessment }\end{array}$} \\
\hline & & & Hazardous & Price & EU Criticality & \\
\hline Raney-Nickel & Catalyst & AWE & High & Medium & High & High \\
\hline Ruthenium & Catalyst & $\begin{array}{l}\text { PEMWE, } \\
\text { PEMFC }\end{array}$ & Low & High & High & High \\
\hline Silica powder & Insulation & SOFC & High & Low & High & High \\
\hline Silver & Ancillary BoP & $\mathrm{BoP}$ & High & High & Medium & High \\
\hline $\begin{array}{l}\text { Strontium-doped } \\
\text { lanthanum } \\
\text { manganite }\end{array}$ & Cathode & SOFC & Medium & Medium & High & High \\
\hline $\begin{array}{l}\text { Yttria-stabilised } \\
\text { zirconia (YSZ) }\end{array}$ & Electrolyte & SOFC & Low-Medium & Medium & High & High \\
\hline Aluminium & Housing & $\begin{array}{l}\text { BoP, PEMFC, } \\
\text { AWE, PEMWE }\end{array}$ & Medium & Low & Medium & Medium \\
\hline Asbestos & Diaphragm & $\begin{array}{l}\text { AWE (older } \\
\text { types) }\end{array}$ & High & Low & Low & Medium \\
\hline Carbon fibres & Electrode & $\begin{array}{l}\text { PEMFC, } \\
\text { PEMWE }\end{array}$ & Medium & Medium & Low & Medium \\
\hline Chromium steel & Housing & BoP & Medium & Low & Medium & Medium \\
\hline Gold & Ancillary BoP & BoP & Low & High & Low & Medium \\
\hline Lead & Batteries & BoP & High & Low & Medium & Medium \\
\hline $\begin{array}{c}\text { Lithium-ion } \\
\left(\mathrm{LiFePO}_{4}\right)\end{array}$ & Batteries & $\mathrm{BoP}$ & Low & Medium & Medium & Medium \\
\hline $\begin{array}{l}\text { Orthophosphoric } \\
\text { acid }\left(\mathrm{H}_{3} \mathrm{PO}_{4}\right)\end{array}$ & Electrolyte & HT-PEMFC & Medium & Low & High & Medium \\
\hline $\begin{array}{l}\text { Perfluorosulphonic } \\
\text { acid } \\
\left(\text { PFSA-Nafion }^{\circledR}\right)\end{array}$ & Electrolyte & $\begin{array}{l}\text { PEMWE, } \\
\text { PEMFC }\end{array}$ & Low-Medium & Medium & Medium & Medium \\
\hline $\begin{array}{l}\text { Polybenzimidazole } \\
\text { (PBI) }\end{array}$ & Membrane & HT-PEMFC & Low & High & Medium & Medium \\
\hline $\begin{array}{l}\text { Polysulfone or. } \\
\text { Polysulfone } \\
\text { composite } \\
\left(\text { Zirfon }^{\circledR}\right)\end{array}$ & Diaphragm & AWE & Low-Medium & Medium-High & Medium & Medium \\
\hline $\begin{array}{l}\text { Polytetraflouroetylen } \\
\text { (PTFE-Teflon) }\end{array}$ & $\begin{array}{c}\text { Catalyst, } \\
\text { Sealant, } \\
\text { Ancillary BoP }\end{array}$ & $\begin{array}{l}\text { AWE, PEMWE, } \\
\text { PEMFC, BoP }\end{array}$ & low & Medium & High & Medium \\
\hline $\begin{array}{l}\text { Potassium } \\
\text { Hydroxide }\end{array}$ & Electrolyte & AWE & Medium & Medium & Low & Medium \\
\hline Silicone & Sealant & $\begin{array}{l}\text { AWE, PEMWE, } \\
\text { PEMFC, BoP }\end{array}$ & Medium & Low & High & Medium \\
\hline Sodium Hydroxide & Electrolyte & AWE & High & Medium & Low & Medium \\
\hline $\begin{array}{c}\text { Sulfonated } \\
\text { polyether ether } \\
\text { ketone (s-PEEK) }\end{array}$ & Electrolyte & $\begin{array}{l}\text { PEMWE, } \\
\text { PEMFC }\end{array}$ & Medium & Medium & Medium & Medium \\
\hline Tin & Batteries & BoP & Medium & Medium & Medium & Medium \\
\hline Titanium & $\begin{array}{l}\text { Electrode, } \\
\text { Interconnect }\end{array}$ & PEMWE & Low-Medium & Medium & Medium & Medium \\
\hline $\begin{array}{l}\text { Titanium Dioxide } \\
\text { Zirconia }\left(\mathrm{ZrO}_{2}\right)\end{array}$ & $\begin{array}{c}\text { Catalyst } \\
\text { Diaphragm }\end{array}$ & $\begin{array}{l}\text { PEMWE } \\
\text { AWE }\end{array}$ & $\begin{array}{l}\text { Medium } \\
\text { Medium }\end{array}$ & $\begin{array}{l}\text { Medium } \\
\text { Medium }\end{array}$ & $\begin{array}{l}\text { Medium } \\
\text { Medium }\end{array}$ & $\begin{array}{l}\text { Medium } \\
\text { Medium }\end{array}$ \\
\hline Carbon black & Catalyst layer & $\begin{array}{l}\text { PEMFC, } \\
\text { PEMWE }\end{array}$ & Medium & Low & Low & Low \\
\hline $\begin{array}{l}\text { Ethylene propylene } \\
\text { diene monomer } \\
\text { (EPDM) }\end{array}$ & Sealing & $\begin{array}{l}\text { AWE, PEMWE, } \\
\text { PEMFC, BoP }\end{array}$ & Medium & Low & Low & Low \\
\hline $\begin{array}{l}\text { Fluroelastomer } \\
\left(\text { FKM-Viton }{ }^{\circledR}\right)\end{array}$ & Sealing & $\begin{array}{l}\text { AWE, PEMWE, } \\
\text { PEMFC, BoP }\end{array}$ & Low & Medium & Low & Low \\
\hline
\end{tabular}


Table 8. Cont

\begin{tabular}{|c|c|c|c|c|c|c|}
\hline \multirow{2}{*}{ Material } & \multirow{2}{*}{ Component } & \multirow{2}{*}{ Technology } & \multicolumn{3}{|c|}{ Methodological Assessment } & \multirow{2}{*}{$\begin{array}{c}\text { New } \\
\text { Assessment }\end{array}$} \\
\hline & & & Hazardous & Price & EU Criticality & \\
\hline Glass wool & Insulation & $\begin{array}{l}\text { BoP, AWE, } \\
\text { PEMWE, } \\
\text { PEMFC }\end{array}$ & Medium & Low & Low & Low \\
\hline $\begin{array}{l}\text { Glass/Glass- } \\
\text { ceramic }\end{array}$ & Sealant & SOFC & Medium & Low & Low & Low \\
\hline Graphite & Interconnect & $\begin{array}{l}\text { PEMFC, } \\
\text { PEMWE }\end{array}$ & Low & Low & Medium & Low \\
\hline $\begin{array}{l}\text { High-density } \\
\text { polyethylene } \\
\text { (HDPE) }\end{array}$ & Ancillary BoP & BoP & Low & Low & Low & Low \\
\hline $\begin{array}{c}\text { Phyllosilicates } \\
\text { (Vermiculite, Mica, } \\
\text {... ) }\end{array}$ & Sealant & SOFC & Medium & Low & Low & Low \\
\hline $\begin{array}{l}\text { Polypropylene (PP) } \\
\text { Polystyrene }\end{array}$ & Ancillary BoP & $\mathrm{BoP}$ & Low & Low & Low & Low \\
\hline $\begin{array}{l}\text { sulfonic acid } \\
\text { (PSSA) }\end{array}$ & Electrolyte & PEMFC & Low & Low & Medium & Low \\
\hline
\end{tabular}

Very critical materials (red color), medium critical materials (yellow color) and low critical materials (green color).

Some parallels can also be drawn between Table 8 and Figure 3, which shows the supply risk of raw materials for the key technologies in the EU. Figure 3 shows that among the key raw materials for the FCH technologies, REEs are the most critical when it comes to supply risk. With our evaluation above, we have shown more specifically which the materials in question are-and additionally shown which materials can be-problematic from the point of view of hazardousness, price and economic importance for the EU.

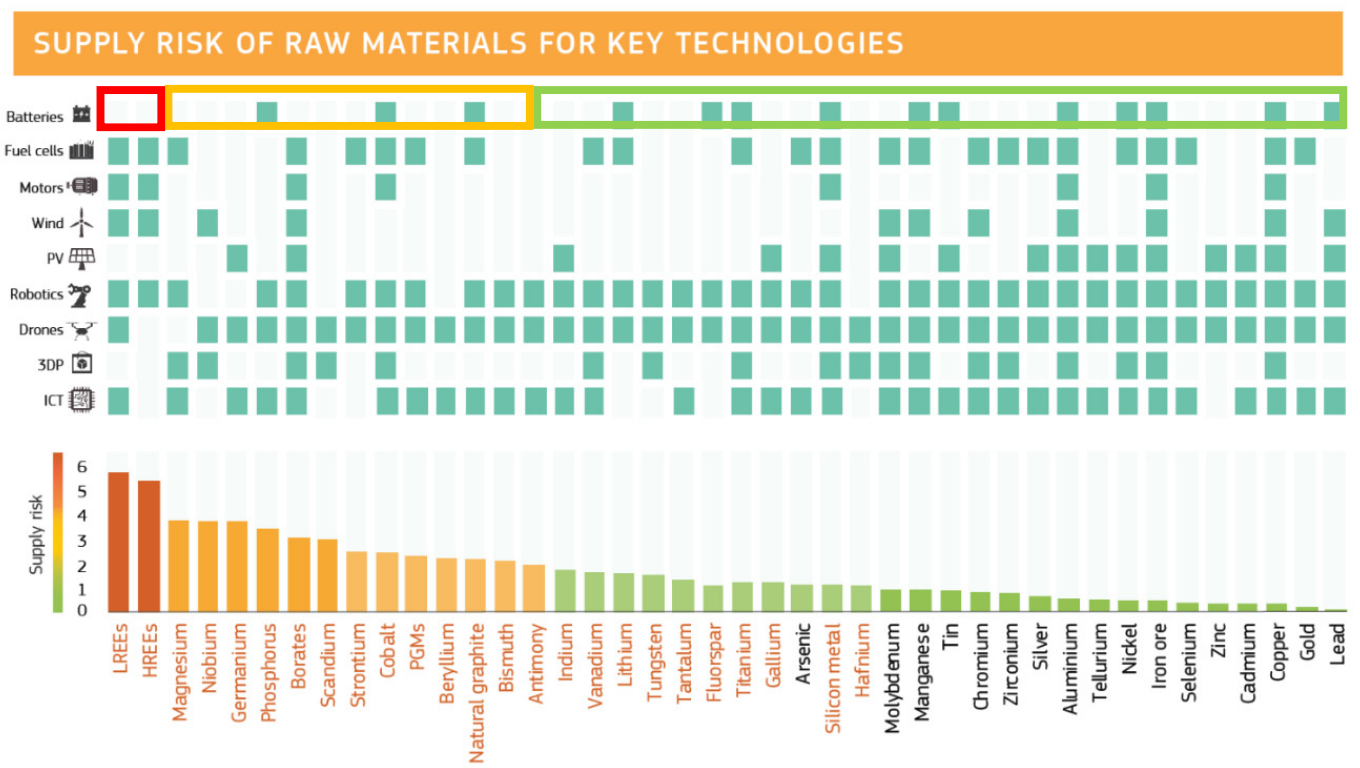

Figure 3. Supply risk of raw materials for key technologies according to the EU's 2020 criticality assessment, [42].

\subsection{Life-Cycle Assessment and Environmental Impacts of FCH Materials}

To further evaluate the importance and criticality of materials used in $\mathrm{FCH}$ technologies, the LCA was performed based on the LCIs presented in the previous section. To provide complete results that are useful for the $\mathrm{FCH}$ industry and manufacturers, the values of the environmental impact indicators are presented in separate tables for each FCH technology and the BoP components. Only the key results are presented and commented 
on below, while the other results of the LCA are added as Supplementary Materials to the paper. For each material, the results of the impact indicators are shown in absolute values, while, similar to the methodological approach, the relative results of each impact indicator across all the materials are colour-coded (red being High and green being Low). The colour coding (the range of relative results) is the same for all the tables, which means all the technologies are directly comparable when it comes to assessing and comparing the environmental impacts of the materials across the different technologies. In addition to the LCIA indicators, the methodological assessment is added in the last column to make an easier comparison of the LCA and the methodological approach. The comparison between the CML2001 and EF3.0 methodologies is only shown in the case of the PEMFC technology. From the analysis of the results, it was concluded that the methodologies are well correlated. For brevity, only the results based on the CML2001 are shown for other technologies, and the results based on EF3.0 are shown in the Supplementary Materials (Tables S1-S5).

\subsubsection{PEMFC Technology}

One of the most mature FCH technologies is the PEMFC, which is mostly used in mobile or smaller stationary applications. In Tables 9 and 10 the environmental impact indicators to produce $1 \mathrm{~g}$ of material used in a PEMFC are presented.

Platinum, as a PGM, has a several-magnitudes-higher environmental impact than other materials. Apart from platinum, Nafion, PTFE (Polytetrafluoroethylene), PEEK (Polyetherether ketone), and silicone are also materials with significant environmental impacts. This is also confirmed by our methodological approach from Table 8 and shown in Table 9 (the last column) and in Table 10 (the last row). The mentioned materials are labelled as High in the case of platinum and Medium in the case of Nafion, PEEK, PTFE and silicone. Another important conclusion is that the majority of materials for the PEMFC technology are already included in the databases. The only exceptions are the carbon fibres, which are substituted by PAN fibres (a common precursor to carbon fibres) and fluroelastomer synthetic rubber (i.e., Viton ${ }^{\circledR}$ ), which is substituted by S-SBR. Also, PAN fibres underestimate the environmental impacts of carbon fibres because this common precursor material undergoes several heat-treatment processes (oxidation and carbonisation) before it is converted to carbon fibres.

- Comparison of CML2001 and EF3.0 Methodologies for the Example of PEMFC Technology 
Table 9. Environmental impact indicators for $1 \mathrm{~g}$ of material used in the PEMFC according to CML2001 methodology.

\begin{tabular}{|c|c|c|c|c|c|c|c|c|c|c|c|c|}
\hline & $\begin{array}{c}\text { ADP } \\
\text { Elements } \\
\text { [kg Sb eq.] }\end{array}$ & $\begin{array}{c}\text { ADP Fossil } \\
{[\mathrm{MJ}]}\end{array}$ & $\begin{array}{c}\mathrm{AP} \\
{[\mathrm{kg} \mathrm{SO}} \\
2 \text { eq.] }]\end{array}$ & $\begin{array}{c}\text { EP } \\
\text { [kg Phosphate eq.] }\end{array}$ & $\begin{array}{l}\text { FAETP Inf. } \\
\text { [kg DCB eq.] }\end{array}$ & $\begin{array}{c}\text { GWP } 100 \\
\text { Years } \\
{\left[\mathrm{kg} \mathrm{CO}_{2} \text { eq.] }\right.}\end{array}$ & $\begin{array}{c}\text { HTP Inf. } \\
\text { [kg DCB eq.] }\end{array}$ & $\begin{array}{l}\text { MAETP Inf. } \\
\text { [kg DCB eq.] }\end{array}$ & $\begin{array}{l}\text { ODP, Steady } \\
\text { State } \\
\text { [kg R11 eq.] }\end{array}$ & $\begin{array}{c}\text { POCP } \\
\text { [kg Ethene eq. }]\end{array}$ & $\begin{array}{l}\text { TETP Inf. } \\
\text { [kg DCB eq.] }\end{array}$ & $\begin{array}{l}\text { Meth. } \\
\text { Approa. }\end{array}$ \\
\hline Platinum & $1.72 \times 10^{-3}$ & $3.38 \times 10^{2}$ & $6.93 \times 10^{-1}$ & $1.79 \times 10^{-2}$ & $2.67 \times 10^{-1}$ & $3.30 \times 10^{1}$ & 9.21 & $3.86 \times 10^{3}$ & $8.57 \times 10^{-14}$ & $3.07 \times 10^{-2}$ & $1.12 \times 10^{-1}$ & High \\
\hline PBI & $3.85 \times 10^{-10}$ & $4.99 \times 10^{-2}$ & $4.22 \times 10^{-6}$ & $1.58 \times 10^{-7}$ & $2.24 \times 10^{-5}$ & $1.88 \times 10^{-3}$ & $7.29 \times 10^{-5}$ & $1.01 \times 10^{-1}$ & $1.20 \times 10^{-17}$ & $4.16 \times 10^{-7}$ & $5.94 \times 10^{-6}$ & Med \\
\hline Nafion & $1.31 \times 10^{-7}$ & 2.12 & $4.10 \times 10^{-4}$ & $9.14 \times 10^{-5}$ & $6.18 \times 10^{-6}$ & $8.31 \times 10^{-1}$ & $3.25 \times 10^{-5}$ & $2.19 \times 10^{-2}$ & $1.83 \times 10^{-15}$ & $9.31 \times 10^{-6}$ & $4.30 \times 10^{-7}$ & Med \\
\hline PEEK & $2.15 \times 10^{-8}$ & $3.42 \times 10^{-1}$ & $5.23 \times 10^{-5}$ & $4.22 \times 10^{-6}$ & $8.28 \times 10^{-5}$ & $1.74 \times 10^{-2}$ & $6.02 \times 10^{-4}$ & $9.13 \times 10^{-1}$ & $4.32 \times 10^{-14}$ & $4.25 \times 10^{-6}$ & $1.23 \times 10^{-5}$ & Med \\
\hline PTFE & $1.60 \times 10^{-6}$ & $2.04 \times 10^{-1}$ & $4.06 \times 10^{-5}$ & $2.86 \times 10^{-6}$ & $3.25 \times 10^{-5}$ & $1.21 \times 10^{-2}$ & $4.03 \times 10^{-4}$ & $7.87 \times 10^{-1}$ & $6.06 \times 10^{-10}$ & $2.97 \times 10^{-6}$ & $9.78 \times 10^{-6}$ & Med \\
\hline PAN & $8.79 \times 10^{-10}$ & $1.10 \times 10^{-1}$ & $1.07 \times 10^{-5}$ & $2.23 \times 10^{-6}$ & $2.45 \times 10^{-5}$ & $5.13 \times 10^{-3}$ & $1.65 \times 10^{-4}$ & $1.82 \times 10^{-1}$ & $2.66 \times 10^{-17}$ & $1.21 \times 10^{-6}$ & $7.52 \times 10^{-6}$ & Med \\
\hline Silicone & $1.53 \times 10^{-7}$ & $8.69 \times 10^{-2}$ & $1.54 \times 10^{-5}$ & $1.63 \times 10^{-6}$ & $2.69 \times 10^{-5}$ & $5.67 \times 10^{-3}$ & $8.79 \times 10^{-4}$ & $5.87 \times 10^{-1}$ & $4.87 \times 10^{-17}$ & $1.96 \times 10^{-6}$ & $9.29 \times 10^{-4}$ & Med \\
\hline EAF Steel & $1.04 \times 10^{-10}$ & $4.04 \times 10^{-3}$ & $9.33 \times 10^{-7}$ & $1.12 \times 10^{-7}$ & $6.03 \times 10^{-7}$ & $3.98 \times 10^{-4}$ & $1.50 \times 10^{-5}$ & $3.32 \times 10^{-2}$ & $1.21 \times 10^{-17}$ & $2.07 \times 10^{-7}$ & $2.33 \times 10^{-6}$ & Low \\
\hline $\begin{array}{l}\text { Stainless } \\
\text { Steel }\end{array}$ & $2.25 \times 10^{-7}$ & $3.50 \times 10^{-2}$ & $2.21 \times 10^{-5}$ & $1.00 \times 10^{-6}$ & $1.42 \times 10^{-4}$ & $3.13 \times 10^{-3}$ & $7.52 \times 10^{-2}$ & 1.26 & $2.03 \times 10^{-17}$ & $1.10 \times 10^{-6}$ & $3.87 \times 10^{-5}$ & Low \\
\hline S-SBR & $5.34 \times 10^{-10}$ & $8.77 \times 10^{-2}$ & $3.58 \times 10^{-6}$ & $5.21 \times 10^{-7}$ & $2.29 \times 10^{-5}$ & $3.06 \times 10^{-3}$ & $1.21 \times 10^{-4}$ & $1.09 \times 10^{-1}$ & $1.15 \times 10^{-17}$ & $7.47 \times 10^{-7}$ & $3.61 \times 10^{-5}$ & Low \\
\hline EPDM & $2.11 \times 10^{-9}$ & $9.52 \times 10^{-2}$ & $4.78 \times 10^{-6}$ & $6.05 \times 10^{-7}$ & $2.52 \times 10^{-5}$ & $3.37 \times 10^{-3}$ & $1.63 \times 10^{-4}$ & $1.85 \times 10^{-1}$ & $1.73 \times 10^{-17}$ & $7.39 \times 10^{-7}$ & $6.78 \times 10^{-6}$ & Low \\
\hline Graphite & $9.37 \times 10^{-11}$ & $2.98 \times 10^{-4}$ & $1.51 \times 10^{-7}$ & $6.75 \times 10^{-8}$ & $1.37 \times 10^{-5}$ & $2.26 \times 10^{-5}$ & $1.80 \times 10^{-5}$ & $3.43 \times 10^{-2}$ & $2.14 \times 10^{-12}$ & $1.02 \times 10^{-8}$ & $1.63 \times 10^{-7}$ & Low \\
\hline
\end{tabular}

For each environmental impact indicator, PEMFC materials are labeled as: high impact (red color), medium impact (yellow color) and low impact (green color). 
Table 10. Environmental impact indicators for $1 \mathrm{~g}$ of material used in the PEMFC according to EF3.0 methodology.

\begin{tabular}{|c|c|c|c|c|c|c|c|c|c|c|c|c|c|}
\hline & Platinum & PBI & Nafion & PEEK & PTFE & Silicone & $\begin{array}{c}\text { Carbon } \\
\text { Black }\end{array}$ & Steel & $\begin{array}{l}\text { Stainless } \\
\text { Steel }\end{array}$ & S-SBR & EPDM & $\begin{array}{l}\text { Carbon } \\
\text { Fibres }\end{array}$ & Graphite \\
\hline $\begin{array}{l}\text { Acid. terrest. and freshwat. [Mole of } \mathrm{H}+ \\
\text { eq.] }\end{array}$ & $7.8 \times 10^{-1}$ & $4.7 \times 10^{-6}$ & $1.7 \times 10^{-6}$ & $6.1 \times 10^{-5}$ & $4.5 \times 10^{-5}$ & $1.8 \times 10^{-5}$ & $5.7 \times 10^{-6}$ & $1.1 \times 10^{-6}$ & $2.5 \times 10^{-5}$ & $4.5 \times 10^{-6}$ & $5.8 \times 10^{-6}$ & $1.4 \times 10^{-5}$ & $1.9 \times 10^{-7}$ \\
\hline Cancer human health effects [CTUh] & $6.7 \times 10^{-9}$ & $9.2 \times 10^{-13}$ & $6.0 \times 10^{-12}$ & $2.7 \times 10^{-12}$ & $1.4 \times 10^{-12}$ & $3.6 \times 10^{-11}$ & $1.1 \times 10^{-12}$ & $1.3 \times 10^{-13}$ & $1.3 \times 10^{-9}$ & $2.1 \times 10^{-12}$ & $1.1 \times 10^{-12}$ & $1.2 \times 10^{-12}$ & $1.1 \times 10^{-14}$ \\
\hline Cancer hum. health eff. (Inorganic) [CTUh] & $2.3 \times 10^{-19}$ & $2.0 \times 10^{-23}$ & & & & $1.2 \times 10^{-21}$ & $1.5 \times 10^{-23}$ & $1.2 \times 10^{-23}$ & $3.0 \times 10^{-23}$ & $1.5 \times 10^{-22}$ & $3.8 \times 10^{-22}$ & $6.0 \times 10^{-22}$ & \\
\hline $\begin{array}{l}\text { Cancer human health effects (Organic) } \\
\text { [CTUh] }\end{array}$ & $1.2 \times 10^{-9}$ & $2.0 \times 10^{-14}$ & $5.8 \times 10^{-12}$ & $8.7 \times 10^{-13}$ & $7.7 \times 10^{-13}$ & $7.3 \times 10^{-13}$ & $2.4 \times 10^{-14}$ & $4.0 \times 10^{-14}$ & $1.3 \times 10^{-9}$ & $2.1 \times 10^{-13}$ & $2.4 \times 10^{-13}$ & $3.3 \times 10^{-13}$ & $3.9 \times 10^{-15}$ \\
\hline Climate Change $\left[\mathrm{kg} \mathrm{CO}_{2}\right.$ eq.] & $3.4 \times 10^{1}$ & $1.9 \times 10^{-3}$ & $9.6 \times 10^{-1}$ & $1.8 \times 10^{-2}$ & $1.2 \times 10^{-2}$ & $5.9 \times 10^{-3}$ & $2.4 \times 10^{-3}$ & $4.1 \times 10^{-4}$ & $3.2 \times 10^{-3}$ & $3.1 \times 10^{-3}$ & $3.5 \times 10^{-3}$ & $5.3 \times 10^{-3}$ & $2.3 \times 10^{-5}$ \\
\hline Climate Change (biogenic) $\left[\mathrm{kg} \mathrm{CO}_{2}\right.$ eq. $]$ & $1.1 \times 10^{-2}$ & $9.6 \times 10^{-6}$ & $1.7 \times 10^{-7}$ & $2.3 \times 10^{-5}$ & $2.9 \times 10^{-5}$ & $3.5 \times 10^{-5}$ & $1.2 \times 10^{-5}$ & $3.5 \times 10^{-6}$ & $6.4 \times 10^{-6}$ & $1.2 \times 10^{-5}$ & $1.3 \times 10^{-5}$ & $1.7 \times 10^{-5}$ & $9.7 \times 10^{-8}$ \\
\hline Climate Change (fossil) $\left[\mathrm{kg} \mathrm{CO}_{2}\right.$ eq.] & $3.4 \times 10^{1}$ & $1.9 \times 10^{-3}$ & $9.6 \times 10^{-1}$ & $1.8 \times 10^{-2}$ & $1.2 \times 10^{-2}$ & $5.8 \times 10^{-3}$ & $2.4 \times 10^{-3}$ & $4.1 \times 10^{-4}$ & $3.2 \times 10^{-3}$ & $3.1 \times 10^{-3}$ & $3.4 \times 10^{-3}$ & $5.2 \times 10^{-3}$ & $2.3 \times 10^{-5}$ \\
\hline Climate $\mathrm{Ch}$. (land use change) [kg CO2eq.] & $4.7 \times 10^{-3}$ & $8.1 \times 10^{-7}$ & $9.8 \times 10^{-8}$ & $9.4 \times 10^{-6}$ & $1.2 \times 10^{-5}$ & $6.2 \times 10^{-6}$ & $1.0 \times 10^{-6}$ & $7.6 \times 10^{-7}$ & $3.9 \times 10^{-6}$ & $2.1 \times 10^{-6}$ & $1.0 \times 10^{-6}$ & $1.5 \times 10^{-6}$ & $3.5 \times 10^{-8}$ \\
\hline Ecotoxicity freshwater (Inorganic) [CTUe] & $4.1 \times 10^{1}$ & $4.6 \times 10^{-2}$ & 1.1 & $1.4 \times 10^{-1}$ & $8.5 \times 10^{-2}$ & $2.6 \times 10^{-2}$ & $5.9 \times 10^{-2}$ & $1.0 \times 10^{-3}$ & $9.6 \times 10^{-3}$ & $3.6 \times 10^{-2}$ & $4.2 \times 10^{-2}$ & $4.1 \times 10^{-2}$ & $3.5 \times 10^{-5}$ \\
\hline Ecotoxicity freshwater (Metals) [CTUe] & $2.0 \times 10^{1}$ & $1.3 \times 10^{-3}$ & $3.3 \times 10^{-4}$ & $1.2 \times 10^{-2}$ & $1.6 \times 10^{-2}$ & $1.0 \times 10^{-2}$ & $1.6 \times 10^{-3}$ & $5.1 \times 10^{-4}$ & $2.8 \times 10^{-3}$ & $1.6 \times 10^{-3}$ & $3.1 \times 10^{-3}$ & $4.3 \times 10^{-3}$ & $2.6 \times 10^{-3}$ \\
\hline Ecotoxicity freshwater (Organic) [CTUe] & $1.2 \times 10^{-1}$ & $2.9 \times 10^{-4}$ & $5.2 \times 10^{-4}$ & $9.3 \times 10^{-4}$ & $3.1 \times 10^{-4}$ & $1.4 \times 10^{-4}$ & $3.7 \times 10^{-4}$ & $6.6 \times 10^{-6}$ & $9.0 \times 10^{-5}$ & $3.1 \times 10^{-4}$ & $3.6 \times 10^{-4}$ & $5.9 \times 10^{-4}$ & $3.2 \times 10^{-6}$ \\
\hline Eutrophication freshwater [kg P eq.] & $3.0 \times 10^{-6}$ & $2.7 \times 10^{-9}$ & $9.4 \times 10^{-10}$ & $5.6 \times 10^{-8}$ & $3.9 \times 10^{-8}$ & $9.8 \times 10^{-9}$ & $3.3 \times 10^{-9}$ & $1.3 \times 10^{-9}$ & $3.9 \times 10^{-9}$ & $5.1 \times 10^{-9}$ & $4.3 \times 10^{-9}$ & $6.9 \times 10^{-9}$ & $1.6 \times 10^{-8}$ \\
\hline Eutrophication marine [kg N eq.] & $5.3 \times 10^{-2}$ & $3.1 \times 10^{-7}$ & $2.9 \times 10^{-7}$ & $9.4 \times 10^{-6}$ & $6.7 \times 10^{-6}$ & $4.1 \times 10^{-6}$ & $3.5 \times 10^{-7}$ & $2.6 \times 10^{-7}$ & $2.7 \times 10^{-6}$ & $1.2 \times 10^{-6}$ & $1.5 \times 10^{-6}$ & $5.4 \times 10^{-6}$ & $3.8 \times 10^{-8}$ \\
\hline Eutrophication terrestrial [Mole of $\mathrm{N}$ eq.] & $5.8 \times 10^{-1}$ & $3.3 \times 10^{-6}$ & $3.2 \times 10^{-6}$ & $9.9 \times 10^{-5}$ & $7.4 \times 10^{-5}$ & $4.5 \times 10^{-5}$ & $3.7 \times 10^{-6}$ & $2.7 \times 10^{-6}$ & $2.9 \times 10^{-5}$ & $1.3 \times 10^{-5}$ & $1.6 \times 10^{-5}$ & $5.4 \times 10^{-5}$ & $4.6 \times 10^{-7}$ \\
\hline n. health [kBq U235 eq.] & $4.9 \times 10^{-1}$ & $3.3 \times 10^{-5}$ & $1.8 \times 10^{-5}$ & $4.8 \times 10^{-4}$ & $5.7 \times 10^{-4}$ & $7.1 \times 10^{-4}$ & $3.6 \times 10^{-5}$ & $2.8 \times 10^{-5}$ & $6.4 \times 10^{-5}$ & $9.6 \times 10^{-5}$ & $2.4 \times 10^{-4}$ & $3.7 \times 10^{-4}$ & $7.8 \times 10^{-6}$ \\
\hline Land Use $[\mathrm{Pt}]$ & 6.4 & $1.9 \times 10^{-3}$ & $2.4 \times 10^{-4}$ & $2.7 \times 10^{-2}$ & $3.3 \times 10^{-2}$ & $2.3 \times 10^{-1}$ & $2.4 \times 10^{-3}$ & $2.0 \times 10^{-3}$ & $6.5 \times 10^{-3}$ & $4.1 \times 10^{-3}$ & $3.4 \times 10^{-3}$ & $5.0 \times 10^{-3}$ & $1.8 \times 10^{-4}$ \\
\hline Non-cancer human health effects [CTUh] & $1.6 \times 10^{-7}$ & $4.4 \times 10^{-11}$ & $7.4 \times 10^{-9}$ & $8.0 \times 10^{-11}$ & $6.0 \times 10^{-11}$ & $4.2 \times 10^{-9}$ & $4.9 \times 10^{-11}$ & $1.6 \times 10^{-11}$ & $1.2 \times 10^{-10}$ & $1.7 \times 10^{-10}$ & $4.6 \times 10^{-11}$ & $5.0 \times 10^{-11}$ & $3.3 \times 10^{-13}$ \\
\hline $\begin{array}{l}\text { Non-cancer human health effects Inorganic) } \\
\text { [CTUh] }\end{array}$ & $2.4 \times 10^{-8}$ & $8.1 \times 10^{-12}$ & $7.4 \times 10^{-9}$ & $3.8 \times 10^{-11}$ & $3.2 \times 10^{-11}$ & $2.2 \times 10^{-11}$ & $1.0 \times 10^{-11}$ & $6.5 \times 10^{-12}$ & $3.8 \times 10^{-12}$ & $7.7 \times 10^{-12}$ & $9.1 \times 10^{-12}$ & $1.0 \times 10^{-11}$ & $6.3 \times 10^{-14}$ \\
\hline $\begin{array}{l}\text { Non-cancer human health effects (Metals) } \\
\text { [CTUh] }\end{array}$ & $1.3 \times 10^{-7}$ & $3.5 \times 10^{-11}$ & $3.2 \times 10^{-12}$ & $4.2 \times 10^{-11}$ & $2.7 \times 10^{-11}$ & $4.2 \times 10^{-9}$ & $3.9 \times 10^{-11}$ & $9.0 \times 10^{-12}$ & $1.2 \times 10^{-10}$ & $1.6 \times 10^{-10}$ & $3.7 \times 10^{-11}$ & $4.0 \times 10^{-11}$ & $2.6 \times 10^{-13}$ \\
\hline $\begin{array}{l}\text { Non-cancer human health effects (Organic) } \\
\text { [CTUh] }\end{array}$ & $5.3 \times 10^{-9}$ & $2.2 \times 10^{-13}$ & $2.8 \times 10^{-11}$ & $2.7 \times 10^{-12}$ & $1.7 \times 10^{-12}$ & $9.5 \times 10^{-13}$ & $2.7 \times 10^{-13}$ & $3.4 \times 10^{-14}$ & $3.2 \times 10^{-13}$ & $5.9 \times 10^{-13}$ & $6.2 \times 10^{-13}$ & $8.2 \times 10^{-13}$ & $6.3 \times 10^{-15}$ \\
\hline Ozone depletion [kg CFC-11 eq.] & $6.4 \times 10^{-14}$ & $9.0 \times 10^{-18}$ & $1.0 \times 10^{-15}$ & $2.4 \times 10^{-14}$ & $4.1 \times 10^{-10}$ & $3.7 \times 10^{-17}$ & $1.1 \times 10^{-17}$ & $9.1 \times 10^{-18}$ & $1.5 \times 10^{-17}$ & $8.6 \times 10^{-18}$ & $1.3 \times 10^{-17}$ & $2.0 \times 10^{-17}$ & $1.9 \times 10^{-12}$ \\
\hline $\begin{array}{l}\text { Photochemical ozone formation-human } \\
\text { health [kg NMVOC eq.] }\end{array}$ & $1.8 \times 10^{-1}$ & $1.7 \times 10^{-6}$ & $1.7 \times 10^{-5}$ & $3.1 \times 10^{-5}$ & $2.3 \times 10^{-5}$ & $1.5 \times 10^{-5}$ & $2.0 \times 10^{-6}$ & $9.5 \times 10^{-7}$ & $8.3 \times 10^{-6}$ & $4.7 \times 10^{-6}$ & $5.5 \times 10^{-6}$ & $1.5 \times 10^{-5}$ & $1.1 \times 10^{-7}$ \\
\hline Resource use, energy carriers [MJ] & $3.6 \times 10^{2}$ & $5.1 \times 10^{-2}$ & 2.8 & $3.5 \times 10^{-1}$ & $2.2 \times 10^{-1}$ & $9.8 \times 10^{-2}$ & $6.4 \times 10^{-2}$ & $4.8 \times 10^{-3}$ & $3.7 \times 10^{-2}$ & $8.9 \times 10^{-2}$ & $9.9 \times 10^{-2}$ & $1.2 \times 10^{-1}$ & $4.3 \times 10^{-4}$ \\
\hline Resource use, mineral\&metals [kg Sb eq.] & $1.7 \times 10^{-3}$ & $2.3 \times 10^{-10}$ & $1.8 \times 10^{-10}$ & $6.1 \times 10^{-9}$ & $1.6 \times 10^{-6}$ & $1.4 \times 10^{-7}$ & $2.8 \times 10^{-10}$ & $1.3 \times 10^{-10}$ & $2.2 \times 10^{-7}$ & $3.5 \times 10^{-10}$ & & & $9.3 \times 10^{-11}$ \\
\hline Respiratory inorg. [Disease incidences] & $8.7 \times 10^{-6}$ & $1.8 \times 10^{-10}$ & $1.1 \times 10^{-11}$ & $6.5 \times 10^{-9}$ & $4.3 \times 10^{-9}$ & $1.9 \times 10^{-10}$ & $2.3 \times 10^{-10}$ & $1.4 \times 10^{-11}$ & $4.6 \times 10^{-10}$ & $3.1 \times 10^{-11}$ & $4.1 \times 10^{-11}$ & $7.0 \times 10^{-11}$ & $1.5 \times 10^{-12}$ \\
\hline Water scarcity [m ${ }^{3}$ world equiv.] & 3.9 & $3.0 \times 10^{-5}$ & $5.9 \times 10^{-2}$ & $2.4 \times 10^{-3}$ & $3.5 \times 10^{-3}$ & $2.0 \times 10^{-3}$ & $3.1 \times 10^{-5}$ & $2.2 \times 10^{-6}$ & $7.1 \times 10^{-4}$ & $2.3 \times 10^{-4}$ & $5.3 \times 10^{-4}$ & $5.3 \times 10^{-4}$ & $1.3 \times 10^{-5}$ \\
\hline methodological app. & High & Med & Med & Med & Med & Med & Low & Low & Low & Low & Low & Low & Low \\
\hline
\end{tabular}

For each environmental impact indicator, PEMFC materials are labeled as: high impact (red color), medium impact (yellow color) and low impact (green color). 
Comparing the environmental impact indicators from the CML2001 (Table 9) and EF3.0 (Table 10) methodologies we can see that in both tables the relative values of the environmental impact indicators are similar (the colours of the individual materials also match well):

- Acidification potential (AP) in the CML2001 corresponds well to Acidification terrestrial and freshwater in EF3.0;

- GWP in CML2001 is almost identical to the Climate change in EF3.0;

- Freshwater eco-toxicity potential (FAETP) in CML2001 has the same relative result (colouring) for the observed materials as four indicators for the Eco-toxicity freshwater in EF3.0. If needed, EF3.0 offers a deeper and more elaborate understanding of freshwater eco-toxicity;

- $\quad$ Ozone-depletion potential (ODP) in CML2001 corresponds well to Ozone depletion in EF3.0;

- Photochemical ozone-creation potential (POCP) in CML corresponds well to Photochemical ozone formation-human health in EF3.0;

- Eutrophication potential in CML2001 corresponds well to the relative results in three eutrophication indicators (freshwater, marine and terrestrial) in EF3.0. By dividing eutrophication into three sub-categories, EF3.0 offers a deeper understanding of this process;

- In terms of human-health effects, the EF3.0 methodology includes some additional indicators that are not present in the CML2001, which offer a more detailed insight into the material's impacts on human health (cancer human health effects, ionising radiation-human health, non-cancer human health effects, respiratory inorganics).

In general, the CML2001 and EF3.0 show a good correlation in the relative results (colouring) for most impact indicators (addressed above). Similar to the case of the PEMFC technology, all the other materials of the considered FCH technologies and BoP components were assessed with the EF3.0 LCIA methodology. For brevity, those results are presented in the supplementary material.

\subsubsection{AWE Technology}

Nickel is classified as critical in the methodological approach (last column in Table 11) and it also shows high environmental impacts in the LCA analysis. Comparing the environmental impacts of all the materials in the AWE technology, nickel and PTFE (polytetrafluoroethylene) have, on average, three-magnitudes-higher environmental impacts, followed by silicone and Zirfone ${ }^{\circledR}$. Only the asbestos production process and sodium hydroxide stand out and have relatively low environmental impacts, compared to the medium result in the methodological approach. Here, the results are a little surprising, because asbestos was banned from use due to its known health effects, causing asbestosis, which can lead to other serious illnesses, such as cancer [77]. Both methodologies fail to recognise and highlight this phenomenon.

\subsubsection{PEMWE Technology}

PGM materials (palladium, platinum and ruthenium) used in the catalyst layer have by far the largest environmental impacts and are assessed as high in criticality, also with the methodological approach (Table 12). It should also be noted that iridium is a common choice for the OER catalyst on the anode side. Unfortunately, as shown in Table 5, there are no data in the standard or extended databases for this material. Since ruthenium is also commonly used as an OER catalyst, and it exhibits similar physical properties, it was used as a replacement material for the LCA. Titanium and Nafion ${ }^{\circledR}$ also have relatively large environmental impacts-especially when compared to materials used in other technologies. PFTE (Teflon) was commented on already in the PEMFC technology as being medium critical. Carbon black, stainless steel, S-SBR and EPDM have low criticality according to the environmental impact indicators and the methodological assessment. 


\subsubsection{SOFC Technology}

The SOFC technology mainly involves REEs, which makes SOFCs critical from the perspective of the EU due to the heavy dependence on REEs imports. As seen from Table 13, they do not have the largest environmental impacts when compared to other technologies. However, it should be noted here that, in the case of cerium (IV) oxide-gadolinium doped, cerium (IV) oxide-samarium doped and lanthanum strontium cobalt ferrite (LCSF), the environmental impacts are underestimated due to the lack of data in the LCI (energy inputs, auxiliary materials and processes, etc.). Lanthanum strontium manganite (LSM), yttria-stabilised zirconia (YSZ), lanthanum chromate and nickel have medium-to-high environmental impacts and are also classified as high in terms of criticality according to the methodological assessment due to the dependence on imports.

\subsubsection{Balance of Plant}

Even though the balance-of-plant (BoP) components represent auxiliary systems for the FCH technology (housing, piping, blowers, pumps, insulation, electronic parts, wires, etc.) they are vital for operations in all FCH technologies. As seen in Table 14, very different materials are used in BoP components (e.g., from palladium that is ranked high in methodological assessment and has high environmental impacts to steel that is low in methodological assessment and has low environmental impacts). There is a notable discrepancy between the environmental impacts and the methodological assessment in the case of gold, which is ranked medium according to the methodological assessment but has extremely high environmental impacts in the production phase. It should be pointed out that it has higher environmental impacts than all the PGM materials. Some discrepancy is also seen in the case of tin, chromium steel and copper. According to our assessment, copper is ranked high in terms of hazardousness because ECHA records state it is very harmful to human health. However, this is not recognised by any of the LCIA methodologies. In the case of tin and chromium steel, the LCIA methods have extended databases and show other environmental impacts not recognised by our methodology. 
Table 11. Environmental impact indicators for $1 \mathrm{~g}$ of material used in the AWE according to CML2001 methodology.

\begin{tabular}{|c|c|c|c|c|c|c|c|c|c|c|c|c|}
\hline & $\begin{array}{c}\text { ADP } \\
\text { Elements } \\
\text { [kg Sb eq.] }\end{array}$ & $\begin{array}{c}\text { ADP Fossil } \\
\text { [MJ] }\end{array}$ & $\begin{array}{c}\mathrm{AP} \\
{\left[\mathrm{kg} \mathrm{SO}{ }_{2} \text { eq. }\right]}\end{array}$ & $\begin{array}{c}\text { EP } \\
{[\mathrm{kg}} \\
\text { Phosphate eq.] }\end{array}$ & $\begin{array}{l}\text { FAETP Inf. } \\
\text { [kg DCB eq.] }\end{array}$ & $\begin{array}{c}\text { GWP } 100 \\
\text { Years } \\
{\left[\mathrm{kg} \mathrm{CO}_{2} \text { eq. }\right]}\end{array}$ & $\begin{array}{c}\text { HTP Inf. } \\
\text { [kg DCB eq.] }\end{array}$ & $\begin{array}{l}\text { MAETP Inf. } \\
\text { [kg DCB } \\
\text { eq.] }\end{array}$ & $\begin{array}{c}\text { ODP, Steady } \\
\text { State } \\
\text { [kg R11 eq.] }\end{array}$ & $\begin{array}{c}\text { POCP } \\
\text { [kg Ethene eq.] }\end{array}$ & $\begin{array}{c}\text { TETP Inf. } \\
\text { [kg DCB eq.] }\end{array}$ & $\begin{array}{l}\text { Methodological } \\
\text { Approach }\end{array}$ \\
\hline Nickel & $6.01 \times 10^{-8}$ & $1.15 \times 10^{-1}$ & $1.58 \times 10^{-3}$ & $3.11 \times 10^{-6}$ & $1.10 \times 10^{-3}$ & $7.66 \times 10^{-3}$ & $4.80 \times 10^{-2}$ & 4.80 & $2.54 \times 10^{-12}$ & $6.40 \times 10^{-5}$ & $3.12 \times 10^{-4}$ & High \\
\hline Zirfone & $1.07 \times 10^{-7}$ & $9.26 \times 10^{-2}$ & $2.42 \times 10^{-5}$ & $1.36 \times 10^{-5}$ & $3.68 \times 10^{-3}$ & $4.81 \times 10^{-3}$ & $8.59 \times 10^{-3}$ & 7.36 & $1.23 \times 10^{-9}$ & $2.80 \times 10^{-6}$ & $4.10 \times 10^{-5}$ & Med \\
\hline Sodium & $1.64 \times 10^{-8}$ & $1.55 \times 10^{-2}$ & $2.59 \times 10^{-6}$ & $5.10 \times 10^{-7}$ & $1.99 \times 10^{-6}$ & $1.32 \times 10^{-3}$ & $3.75 \times 10^{-5}$ & $9.07 \times 10^{-2}$ & $3.36 \times 10^{-17}$ & $2.10 \times 10^{-7}$ & $1.57 \times 10^{-6}$ & Med \\
\hline Silicone & $1.53 \times 10^{-7}$ & $8.69 \times 10^{-2}$ & $1.54 \times 10^{-5}$ & $1.63 \times 10^{-6}$ & $2.69 \times 10^{-5}$ & $5.67 \times 10^{-3}$ & $8.79 \times 10^{-4}$ & $5.87 \times 10^{-1}$ & $4.87 \times 10^{-17}$ & $1.96 \times 10^{-6}$ & $9.29 \times 10^{-4}$ & Med \\
\hline Asbestos & $9.28 \times 10^{-11}$ & $4.78 \times 10^{-4}$ & $2.22 \times 10^{-7}$ & $7.21 \times 10^{-8}$ & $1.56 \times 10^{-5}$ & $3.71 \times 10^{-5}$ & $2.56 \times 10^{-5}$ & $5.29 \times 10^{-2}$ & $1.55 \times 10^{-12}$ & $1.48 \times 10^{-8}$ & $1.86 \times 10^{-7}$ & Med \\
\hline $\begin{array}{l}\text { Potass. } \\
\text { hydroxide }\end{array}$ & $7.62 \times 10^{-8}$ & $2.53 \times 10^{-2}$ & $8.60 \times 10^{-6}$ & $4.51 \times 10^{-6}$ & $1.85 \times 10^{-3}$ & $1.75 \times 10^{-3}$ & $3.19 \times 10^{-3}$ & 3.40 & $1.91 \times 10^{-10}$ & $5.49 \times 10^{-7}$ & $2.14 \times 10^{-5}$ & Med \\
\hline $\begin{array}{l}\text { Stainless } \\
\text { steel }\end{array}$ & $2.25 \times 10^{-7}$ & $3.50 \times 10^{-2}$ & $2.21 \times 10^{-5}$ & $1.00 \times 10^{-6}$ & $1.42 \times 10^{-4}$ & $3.13 \times 10^{-3}$ & $7.52 \times 10^{-2}$ & 1.26 & $2.03 \times 10^{-17}$ & $1.10 \times 10^{-6}$ & $3.87 \times 10^{-5}$ & Low \\
\hline S-SBR & $5.34 \times 10^{-10}$ & $8.77 \times 10^{-2}$ & $3.58 \times 10^{-6}$ & $5.21 \times 10^{-7}$ & $2.29 \times 10^{-5}$ & $3.06 \times 10^{-3}$ & $1.21 \times 10^{-4}$ & $1.09 \times 10^{-1}$ & $1.15 \times 10^{-17}$ & $7.47 \times 10^{-7}$ & $3.61 \times 10^{-5}$ & Low \\
\hline EPDM & $2.11 \times 10^{-9}$ & $9.52 \times 10^{-2}$ & $4.78 \times 10^{-6}$ & $6.05 \times 10^{-7}$ & $2.52 \times 10^{-5}$ & $3.37 \times 10^{-3}$ & $1.63 \times 10^{-4}$ & $1.85 \times 10^{-1}$ & $1.73 \times 10^{-17}$ & $7.39 \times 10^{-7}$ & $6.78 \times 10^{-6}$ & Low \\
\hline
\end{tabular}

For each environmental impact indicator, AWE materials are labeled as: high impact (red color), medium impact (yellow color) and low impact (green color). 
Table 12. Environmental impact indicators for $1 \mathrm{~g}$ of material used in the PEMWE according to CML2001 methodology.

\begin{tabular}{|c|c|c|c|c|c|c|c|c|c|c|c|c|}
\hline & $\begin{array}{c}\text { ADP } \\
\text { Elements } \\
\text { [kg Sb eq.] }\end{array}$ & $\begin{array}{c}\text { ADP Fossil } \\
{[\mathrm{MJ}]}\end{array}$ & $\begin{array}{c}\mathrm{AP} \\
{\left[\mathrm{kg} \mathrm{SO} \mathrm{O}_{2} \text { eq.] }\right.}\end{array}$ & $\begin{array}{c}\text { EP } \\
\text { [kg Phosphate } \\
\text { eq.] }\end{array}$ & $\begin{array}{l}\text { FAETP Inf. } \\
\text { [kg DCB eq.] }\end{array}$ & $\begin{array}{c}\text { GWP } 100 \\
\text { Years } \\
{\left[\mathrm{kg} \mathrm{CO}_{2} \text { eq.] }\right.}\end{array}$ & $\begin{array}{c}\text { HTP Inf. } \\
\text { [kg DCB eq.] }\end{array}$ & $\begin{array}{l}\text { MAETP Inf. } \\
\text { [kg DCB eq.] }\end{array}$ & $\begin{array}{l}\text { ODP, Steady } \\
\text { State } \\
\text { [kg R11 eq.] }\end{array}$ & $\begin{array}{c}\text { POCP } \\
\text { [kg Ethene eq.] }\end{array}$ & $\begin{array}{c}\text { TETP Inf. } \\
\text { [kg DCB eq.] }\end{array}$ & $\begin{array}{c}\text { Meth. } \\
\text { Approach }\end{array}$ \\
\hline Palladium & $1.20 \times 10^{-3}$ & $3.05 \times 10^{2}$ & 1.01 & $1.55 \times 10^{-2}$ & $5.84 \times 10^{-1}$ & $2.74 \times 10^{1}$ & $1.82 \times 10^{1}$ & $4.19 \times 10^{3}$ & $6.09 \times 10^{-14}$ & $4.33 \times 10^{-2}$ & $1.99 \times 10^{-1}$ & High \\
\hline Platinum & $1.72 \times 10^{-3}$ & $3.38 \times 10^{2}$ & $6.93 \times 10^{-1}$ & $1.79 \times 10^{-2}$ & $2.67 \times 10^{-1}$ & $3.30 \times 10^{1}$ & 9.21 & $3.86 \times 10^{3}$ & $8.57 \times 10^{-14}$ & $3.07 \times 10^{-2}$ & $1.12 \times 10^{-1}$ & High \\
\hline Nafion & $1.31 \times 10^{-7}$ & 2.12 & $4.10 \times 10^{-4}$ & $9.14 \times 10^{-5}$ & $6.18 \times 10^{-6}$ & $8.31 \times 10^{-1}$ & $3.25 \times 10^{-5}$ & $2.19 \times 10^{-2}$ & $1.83 \times 10^{-15}$ & $9.31 \times 10^{-6}$ & $4.30 \times 10^{-7}$ & Med \\
\hline PEEK & $2.15 \times 10^{-8}$ & $3.42 \times 10^{-1}$ & $5.23 \times 10^{-5}$ & $4.22 \times 10^{-6}$ & $8.28 \times 10^{-5}$ & $1.74 \times 10^{-2}$ & $6.02 \times 10^{-4}$ & $9.13 \times 10^{-1}$ & $4.32 \times 10^{-14}$ & $4.25 \times 10^{-6}$ & $1.23 \times 10^{-5}$ & Med \\
\hline PTFE & $1.60 \times 10^{-6}$ & $2.04 \times 10^{-1}$ & $4.06 \times 10^{-5}$ & $2.86 \times 10^{-6}$ & $3.25 \times 10^{-5}$ & $1.21 \times 10^{-2}$ & $4.03 \times 10^{-4}$ & $7.87 \times 10^{-1}$ & $6.06 \times 10^{-10}$ & $2.97 \times 10^{-6}$ & $9.78 \times 10^{-6}$ & Med \\
\hline Silicone & $1.53 \times 10^{-7}$ & $8.69 \times 10^{-2}$ & $1.54 \times 10^{-5}$ & $1.63 \times 10^{-6}$ & $2.69 \times 10^{-5}$ & $5.67 \times 10^{-3}$ & $8.79 \times 10^{-4}$ & $5.87 \times 10^{-1}$ & $4.87 \times 10^{-17}$ & $1.96 \times 10^{-6}$ & $9.29 \times 10^{-4}$ & Med \\
\hline Titanium & $2.06 \times 10^{-7}$ & $4.06 \times 10^{-1}$ & $1.41 \times 10^{-4}$ & $8.45 \times 10^{-5}$ & $1.61 \times 10^{-2}$ & $2.96 \times 10^{-2}$ & $1.96 \times 10^{-2}$ & $4.74 \times 10^{1}$ & $2.76 \times 10^{-9}$ & $2.12 \times 10^{-5}$ & $1.03 \times 10^{-4}$ & Med \\
\hline $\begin{array}{l}\text { Titanium } \\
\text { dioxide }\end{array}$ & $7.75 \times 10^{-8}$ & $7.00 \times 10^{-2}$ & $1.26 \times 10^{-4}$ & $1.48 \times 10^{-5}$ & $4.53 \times 10^{-3}$ & $5.46 \times 10^{-3}$ & $5.78 \times 10^{-3}$ & $2.27 \times 10^{1}$ & $5.44 \times 10^{-10}$ & $5.92 \times 10^{-6}$ & $3.49 \times 10^{-5}$ & Med \\
\hline $\begin{array}{l}\text { Carbon } \\
\text { black }\end{array}$ & $4.68 \times 10^{-10}$ & $6.34 \times 10^{-2}$ & $5.14 \times 10^{-6}$ & $1.86 \times 10^{-7}$ & $2.86 \times 10^{-5}$ & $2.35 \times 10^{-3}$ & $9.21 \times 10^{-5}$ & $1.22 \times 10^{-1}$ & $1.50 \times 10^{-17}$ & $5.16 \times 10^{-7}$ & $6.09 \times 10^{-6}$ & Low \\
\hline $\begin{array}{l}\text { Stainless } \\
\text { steel }\end{array}$ & $2.25 \times 10^{-7}$ & $3.50 \times 10^{-2}$ & $2.21 \times 10^{-5}$ & $1.00 \times 10^{-6}$ & $1.42 \times 10^{-4}$ & $3.13 \times 10^{-3}$ & $7.52 \times 10^{-2}$ & 1.26 & $2.03 \times 10^{-17}$ & $1.10 \times 10^{-6}$ & $3.87 \times 10^{-5}$ & Low \\
\hline S-SBR & $5.34 \times 10^{-10}$ & $8.77 \times 10^{-2}$ & $3.58 \times 10^{-6}$ & $5.21 \times 10^{-7}$ & $2.29 \times 10^{-5}$ & $3.06 \times 10^{-3}$ & $1.21 \times 10^{-4}$ & $1.09 \times 10^{-1}$ & $1.15 \times 10^{-17}$ & $7.47 \times 10^{-7}$ & $3.61 \times 10^{-5}$ & Low \\
\hline EPDM & $2.11 \times 10^{-9}$ & $9.52 \times 10^{-2}$ & $4.78 \times 10^{-6}$ & $6.05 \times 10^{-7}$ & $2.52 \times 10^{-5}$ & $3.37 \times 10^{-3}$ & $1.63 \times 10^{-4}$ & $1.85 \times 10^{-1}$ & $1.73 \times 10^{-17}$ & $7.39 \times 10^{-7}$ & $6.78 \times 10^{-6}$ & Low \\
\hline PAN & $8.79 \times 10^{-10}$ & $1.10 \times 10^{-1}$ & $1.07 \times 10^{-5}$ & $2.23 \times 10^{-6}$ & $2.45 \times 10^{-5}$ & $5.13 \times 10^{-3}$ & $1.65 \times 10^{-4}$ & $1.82 \times 10^{-1}$ & $2.66 \times 10^{-17}$ & $1.21 \times 10^{-6}$ & $7.52 \times 10^{-6}$ & Low \\
\hline
\end{tabular}

For each environmental impact indicator, PEMWE materials are labeled as: high impact (red color), medium impact (yellow color) and low impact (green color).

Table 13. Environmental impact indicators for $1 \mathrm{~g}$ of material used in the SOFC according to CML2001 methodology.

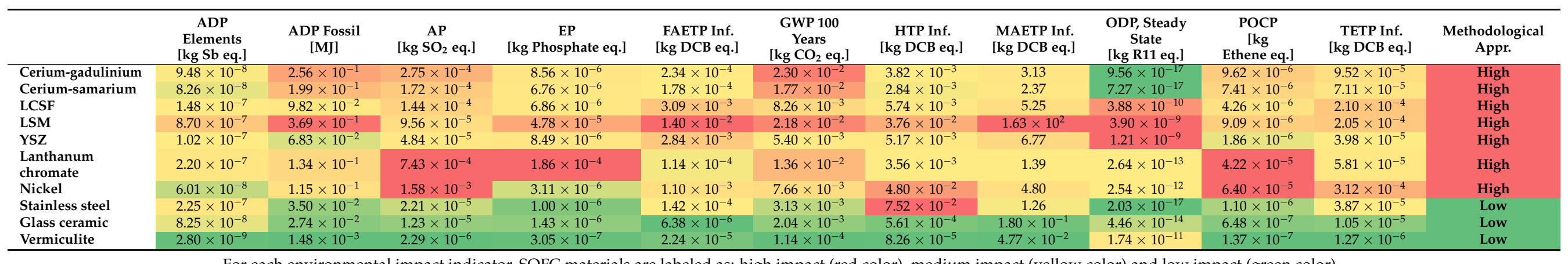

For each environmental impact indicator, SOFC materials are labeled as: high impact (red color), medium impact (yellow color) and low impact (green color). 
Table 14. Environmental impact indicators for $1 \mathrm{~g}$ of material used in the BoP according to CML2001 methodology.

\begin{tabular}{|c|c|c|c|c|c|c|c|c|c|c|c|c|}
\hline & $\begin{array}{c}\text { ADP } \\
\text { Elements } \\
\text { [kg Sb eq.] }\end{array}$ & $\begin{array}{c}\text { ADP Fossil } \\
{[\mathrm{MJ}]}\end{array}$ & $\begin{array}{c}\mathrm{AP} \\
{\left[\mathrm{kg} \mathrm{SO}{ }_{2} \text { eq. }\right]}\end{array}$ & $\begin{array}{c}\text { EP } \\
\text { [kg Phosphate eq.] }\end{array}$ & $\begin{array}{l}\text { FAETP Inf. } \\
\text { [kg DCB eq.] }\end{array}$ & $\begin{array}{c}\text { GWP 100 } \\
\text { Years } \\
{\left[\mathrm{kg} \mathrm{CO}_{2} \text { eq.] }\right.}\end{array}$ & $\begin{array}{c}\text { HTP Inf. } \\
\text { [kg DCB eq.] }\end{array}$ & $\begin{array}{l}\text { MAETP Inf. } \\
\text { [kg DCB eq.] }\end{array}$ & $\begin{array}{c}\text { ODP, Steady } \\
\text { State } \\
\text { [kg R11 eq.] }\end{array}$ & $\begin{array}{c}\text { РОСР } \\
{[\mathrm{kg}} \\
\text { Ethene eq. }]\end{array}$ & $\begin{array}{c}\text { TETP Inf. } \\
\text { [kg DCB eq.] }\end{array}$ & $\begin{array}{l}\text { Methodological } \\
\text { Appr. }\end{array}$ \\
\hline Copper & $3.19 \times 10^{-6}$ & $4.02 \times 10^{-2}$ & $6.51 \times 10^{-5}$ & $1.47 \times 10^{-6}$ & $1.33 \times 10^{-4}$ & $3.98 \times 10^{-3}$ & $7.59 \times 10^{-3}$ & 2.81 & $2.36 \times 10^{-17}$ & $2.93 \times 10^{-6}$ & $4.27 \times 10^{-5}$ & High \\
\hline Palladium & $1.20 \times 10^{-3}$ & $3.05 \times 10^{2}$ & 1.01 & $1.55 \times 10^{-2}$ & $5.84 \times 10^{-1}$ & $2.74 \times 10^{1}$ & $1.82 \times 10^{1}$ & $4.19 \times 10^{3}$ & $6.09 \times 10^{-14}$ & $4.33 \times 10^{-2}$ & $1.99 \times 10^{-1}$ & High \\
\hline Silver & $7.53 \times 10^{-5}$ & $9.81 \times 10^{-1}$ & $8.33 \times 10^{-3}$ & $2.82 \times 10^{-5}$ & $1.36 \times 10^{-3}$ & $8.15 \times 10^{-2}$ & $9.12 \times 10^{-1}$ & $1.38 \times 10^{1}$ & $3.10 \times 10^{-16}$ & $3.39 \times 10^{-4}$ & $4.48 \times 10^{-3}$ & High \\
\hline Lead & $2.45 \times 10^{-6}$ & $1.61 \times 10^{-2}$ & $3.97 \times 10^{-5}$ & $4.07 \times 10^{-7}$ & $9.38 \times 10^{-6}$ & $1.50 \times 10^{-3}$ & $4.78 \times 10^{-4}$ & $7.25 \times 10^{-2}$ & $6.26 \times 10^{-18}$ & $1.83 \times 10^{-6}$ & $5.51 \times 10^{-6}$ & Med \\
\hline $\begin{array}{l}\text { Lithium-ion } \\
\left(\mathrm{LiFePO}_{4}\right)\end{array}$ & $3.80 \times 10^{-8}$ & $1.53 \times 10^{-1}$ & $4.35 \times 10^{-5}$ & $5.27 \times 10^{-6}$ & $6.51 \times 10^{-5}$ & $1.02 \times 10^{-2}$ & $8.28 \times 10^{-4}$ & $7.62 \times 10^{-1}$ & $1.25 \times 10^{-13}$ & $3.01 \times 10^{-6}$ & $7.51 \times 10^{-5}$ & Med \\
\hline PTFE & $1.60 \times 10^{-6}$ & $2.04 \times 10^{-1}$ & $4.06 \times 10^{-5}$ & $2.86 \times 10^{-6}$ & $3.25 \times 10^{-5}$ & $1.21 \times 10^{-2}$ & $4.03 \times 10^{-4}$ & $7.87 \times 10^{-1}$ & $6.06 \times 10^{-10}$ & $2.97 \times 10^{-6}$ & $9.78 \times 10^{-6}$ & Med \\
\hline Silicon & $1.53 \times 10^{-7}$ & $8.69 \times 10^{-2}$ & $1.54 \times 10^{-5}$ & $1.63 \times 10^{-6}$ & $2.69 \times 10^{-5}$ & $5.67 \times 10^{-3}$ & $8.79 \times 10^{-4}$ & $5.87 \times 10^{-1}$ & $4.87 \times 10^{-17}$ & $1.96 \times 10^{-6}$ & $9.29 \times 10^{-4}$ & Med \\
\hline Gold & $5.20 \times 10^{-2}$ & $6.30 \times 10^{2}$ & $6.06 \times 10^{-1}$ & $4.17 \times 10^{-2}$ & $6.29 \times 10^{-2}$ & $6.14 \times 10^{1}$ & 4.19 & $5.54 \times 10^{3}$ & $1.91 \times 10^{-13}$ & $3.08 \times 10^{-2}$ & $7.56 \times 10^{-2}$ & Med \\
\hline Tin & $2.70 \times 10^{-5}$ & $1.40 \times 10^{-1}$ & $1.11 \times 10^{-4}$ & $9.66 \times 10^{-5}$ & $8.17 \times 10^{-2}$ & $1.10 \times 10^{-2}$ & $7.68 \times 10^{-2}$ & $9.39 \times 10^{1}$ & $6.90 \times 10^{-10}$ & $6.81 \times 10^{-6}$ & $1.45 \times 10^{-4}$ & Med \\
\hline Aluminium & $3.81 \times 10^{-9}$ & $1.51 \times 10^{-1}$ & $1.05 \times 10^{-4}$ & $6.81 \times 10^{-6}$ & $1.29 \times 10^{-4}$ & $1.59 \times 10^{-2}$ & $1.96 \times 10^{-2}$ & $2.48 \times 10^{1}$ & $1.61 \times 10^{-15}$ & $6.70 \times 10^{-6}$ & $9.11 \times 10^{-5}$ & Med \\
\hline Regular steel & $1.04 \times 10^{-10}$ & $4.04 \times 10^{-3}$ & $9.33 \times 10^{-7}$ & $1.12 \times 10^{-7}$ & $6.03 \times 10^{-7}$ & $3.98 \times 10^{-4}$ & $1.50 \times 10^{-5}$ & $3.32 \times 10^{-2}$ & $1.21 \times 10^{-17}$ & $2.07 \times 10^{-7}$ & $2.33 \times 10^{-6}$ & Low \\
\hline Stainless Steel & $2.25 \times 10^{-7}$ & $3.50 \times 10^{-2}$ & $2.21 \times 10^{-5}$ & $1.00 \times 10^{-6}$ & $1.42 \times 10^{-4}$ & $3.13 \times 10^{-3}$ & $7.52 \times 10^{-2}$ & 1.26 & $2.03 \times 10^{-17}$ & $1.10 \times 10^{-6}$ & $3.87 \times 10^{-5}$ & Low \\
\hline EPDM & $2.11 \times 10^{-9}$ & $9.52 \times 10^{-2}$ & $4.78 \times 10^{-6}$ & $6.05 \times 10^{-7}$ & $2.52 \times 10^{-5}$ & $3.37 \times 10^{-3}$ & $1.63 \times 10^{-4}$ & $1.85 \times 10^{-1}$ & $1.73 \times 10^{-17}$ & $7.39 \times 10^{-7}$ & $6.78 \times 10^{-6}$ & Low \\
\hline Glass wool & $2.00 \times 10^{-7}$ & $3.40 \times 10^{-2}$ & $9.77 \times 10^{-6}$ & $1.79 \times 10^{-6}$ & $4.72 \times 10^{-6}$ & $2.23 \times 10^{-3}$ & $6.87 \times 10^{-5}$ & $3.58 \times 10^{-1}$ & $4.51 \times 10^{-17}$ & $4.57 \times 10^{-7}$ & $3.54 \times 10^{-6}$ & Low \\
\hline HDPE & $5.04 \times 10^{-11}$ & $7.31 \times 10^{-2}$ & $4.11 \times 10^{-6}$ & $2.78 \times 10^{-6}$ & $9.66 \times 10^{-5}$ & $1.79 \times 10^{-3}$ & $3.55 \times 10^{-4}$ & $2.17 \times 10^{-1}$ & $3.48 \times 10^{-13}$ & $1.03 \times 10^{-6}$ & $1.61 \times 10^{-6}$ & Low \\
\hline PP & $1.45 \times 10^{-10}$ & $7.10 \times 10^{-2}$ & $4.19 \times 10^{-6}$ & $2.79 \times 10^{-6}$ & $9.96 \times 10^{-5}$ & $1.63 \times 10^{-3}$ & $3.75 \times 10^{-4}$ & $2.29 \times 10^{-1}$ & $1.24 \times 10^{-14}$ & $7.58 \times 10^{-7}$ & $2.21 \times 10^{-6}$ & Low \\
\hline
\end{tabular}

For each environmental impact indicator, BoP materials are labeled as: high impact (red color), medium impact (yellow color) and low impact (green color). 


\section{Discussion}

The comparison of materials used in FCH technologies revealed that the PEMWE technology includes the largest number of different PGM materials. Also, titanium must be used as a catalyst support and for interconnects (bipolar plates), because it can withstand electrochemical corrosion at higher voltage potentials. Assessed purely on a materials basis, the use of PGMs and titanium ranks the PEMWE highest in material criticality and has the greatest impact on the environment. The PEMFC, as the most mature and technologically developed FCH technology, is mainly based on platinum catalysts. In the last decades, the R\&D in PEM technology (fuel cells and electrolysers) has been focused on lowering the PGM loadings in catalysts. From this study it can be concluded that this has had a very positive effect, because it significantly contributes to decreasing the environmental impacts in the production process. The other possibility is to find substitute materials for catalysts (i.e., PGM alloys or even non-noble catalysts). All these measures will bring the technology down the criticality ladder. Except for platinum, and to some extent the Nafion ${ }^{\circledR}$ membrane, the PEMFC technology shows very moderate environmental impacts. The SOFC consists mainly of rare earth elements (REEs), which also puts the technology high on the criticality ladder, due to the dependence of the EU on imports of REEs. A potential threat to this technology could be the total mass of required REEs, because it represents a large weight ratio of the entire system. However, REEs also have relatively moderate environmental impacts, which makes the technology very interesting for further research. In contrast, the AWE technology does not use PGMs or REEs and it is therefore the lowest on the criticality ladder. Also, the environmental impacts are very moderate and are mainly attributed to the use of nickel for the catalysts and interconnects. However, some speculations can also be raised about the diaphragm (membrane) material. Older AWEs used asbestos, while current AWEs use Zirfon ${ }^{\circledR}$. Both LCA methodologies do not recognise asbestos as being hazardous. As a matter of fact, it shows smaller environmental impacts than the commonly used Zirfon ${ }^{\circledR}$ diaphragms, although it is well known that asbestos is hazardous to human health and its use is now prohibited. Compared to other materials in AWE technology, the Zirfon ${ }^{\circledR}$ diaphragm shows rather large environmental impacts. R\&D is working on a new generation of AWEs, the so-called zero-gap technology (similar concept to PEM technology), where anion-exchange membranes (AEMs) are used. Successfully implementing this concept can further decrease the environmental impacts of the AWE technology. In BoP components the largest environmental impacts and high material criticality are shown by the precious metals (gold, silver) and small amounts of PGMs (mostly palladium). The largest discrepancy between the methodological approach and the LCA approach can be seen in the case of gold. However, as already mentioned, gold has by far the largest environmental impact among all the materials, but it is not ranked as a critical raw material. This study, which partially originates from past EU-funded projects, represents a very important input for future projects with which the EU wants to set out much needed guidance documents for eco-design and a sustainable and efficient approach to end-of-life fuel-cell and hydrogen technologies.

\section{Conclusions}

The materials used in fuel-cell and hydrogen (FCH) technologies were assessed using a novel methodological assessment and with a life-cycle assessment (LCA) approach. The focus was on the identification and assessment of all the materials used in the four most mature FCH technologies: polymer-electrolyte-membrane fuel cells, solid-oxide fuel cells, polymer-electrolyte-membrane water electrolysers and alkaline water electrolysers. Although balance-of-plant components are not the primary focus of this paper, common materials used to manufacture them were also assessed. This new methodological assessment is a combination of three separately used criteria for the assessment of material criticality: (a) hazardousness, (b) price and (c) EU criticality methodology. It enabled a faster (preliminary) ranking and the identification of materials and was also used to build the life-cycle inventory (LCI) lists for the LCA analyses. The LCA approach was 
used to obtain a deeper understanding of the environmental impacts of materials and to verify the new methodological approach. All the LCA analyses were made only for the manufacturing phase (cradle-to-gate analysis) using $1 \mathrm{~g}$ of material as a functional unit. From the results it can be seen that the platinum group metals (PGMs) are extremely high in terms of criticality and have very large environmental impacts, while rare-earth elements also show a high material criticality, but only moderate environmental impacts. Only gold has a larger environmental impact than the PGMs; however, it is not ranked as a critical raw material according to the EU criticality methodology. The results from this study show the importance of treating all (not just critical) materials in $\mathrm{FCH}$ technologies. Especially because in real systems the mass ratio of materials is very different (unlike in our study, where all the impacts are normalised per $1 \mathrm{~g}$ of material) and sometimes small amounts of very critical materials can have significant environmental impacts. On the other hand, large quantities (a high weight ratio in the total mass of the system) of seemingly uncritical material can overwhelm the contribution of an otherwise critical material. It should be stressed that relevant and up-to-date LCI databases-that include all FCH materials, their mass ratios in $\mathrm{FCH}$ technologies, exact production processes of materials and the components, followed by end-of-life scenarios-should be one of the main agendas for the FCH industry and policymakers in order to achieve lower environmental impacts and the higher sustainability of FCH technologies.

Supplementary Materials: The following are available online at https:/ / www.mdpi.com/2071-1 050/13/6/3565/s1, Table S1: Environmental LCIA results for SOFC according EF3.0 methodology per $1 \mathrm{~g}$ of material, Table S2: Environmental LCIA results for PEMWE according EF3.0 methodology per 1g of material, Table S3: Environmental LCIA results for AWE according EF3.0 methodology per 1g of material, Table S4: Environmental LCIA results for BoP according EF3.0 methodology per $1 \mathrm{~g}$ of material, Table S5: Environmental LCIA results for all FCH materials according CML2001 methodology per $1 \mathrm{~g}$ of material.

Author Contributions: Conceptualization, M.M. and A.L.; Data curation, M.M. and R.S.; Formal analysis, M.S. and A.L.; Funding acquisition, M.M. and M.S.; Investigation, R.S. and A.L.; Methodology, M.M., R.S. and A.L.; Project administration, M.M. and M.S.; Resources, R.S. and A.L.; Software, M.M. and R.S.; Supervision, M.S.; Validation, M.M. and A.L.; Writing—original draft, M.M., R.S. and A.L.; Writing-review \& editing, M.S. and A.L. All authors have read and agreed to the published version of the manuscript.

Funding: This project has received funding from the Fuel Cells and Hydrogen 2 Joint Undertaking under grant agreements No 700190 and No 101007216. This Joint Undertaking receives support from the European Union's Horizon 2020 research and innovation programme, Hydrogen Europe and Hydrogen Europe research. The authors also acknowledge the financial support by the Slovenian Research Agency (research core funding No. P2-0401).

Institutional Review Board Statement: Not applicable.

Informed Consent Statement: Not applicable.

Data Availability Statement: Data is contained within the article and Supplementary Material.

Acknowledgments: This study was carried out in the frame of the European H2020 HyTechCycling and Best4Hy projects and supported by the Slovenian Research Agency.

Conflicts of Interest: The authors declare no conflict of interest.

\section{References}

1. United Nations. Adoption of the Paris Agreement; United Nations Framework Convention on Climate Change: Paris, France, 2015.

2. European Commission. The European Green Deal; European Commission: Brussels, Belgium, 2019; Volume 53.

3. International Energy Agency. The Future of Hydrogen—Seizing Today's Opportunities—Report Prepared for the G20, Japan; International Energy Agency: Paris, France, 2019.

4. Hydrogen Council. Hydrogen—Scaling Up; Hydrogen Council: Brussels, Belgium, 2017.

5. Hyacinth Project. Available online: http://hyacinthproject.eu/ (accessed on 25 February 2019). 
6. Wright, E.I.; Rahimifard, S. Strategic Decision Making for End-of-Life Management of Fuel Cells. Leveraging Technol. Sustain. World 2012, 185-190. [CrossRef]

7. Schmidt, O.; Gambhir, A.; Staffell, I.; Hawkes, A.; Nelson, J.; Few, S. Future cost and performance of water electrolysis: An expert elicitation study. Int. J. Hydrogen Energy 2017, 42, 30470-30492. [CrossRef]

8. Chi, J.; Yu, H. Water electrolysis based on renewable energy for hydrogen production. Chin. J. Catal. 2018, 39, 390-394. [CrossRef]

9. Ho, J.C.; Saw, E.C.; Lu, L.Y.Y.; Liu, J.S. Technological barriers and research trends in fuel cell technologies: A citation network analysis. Technol. Forecast. Soc. Chang. 2014, 82, 66-79. [CrossRef]

10. Sharaf, O.Z.; Orhan, M.F. An overview of fuel cell technology: Fundamentals and applications. Renew. Sustain. Energy Rev. 2014, 32, 810-853. [CrossRef]

11. Alaswad, A.; Palumbo, A.; Dassisti, M.; Olabi, A.G. Fuel Cell Technologies, Applications, and State of the Art. A Reference Guide; Elsevier Ltd.: Amsterdam, The Netherlands, 2016; ISBN 978-0-12-803581-8.

12. Wilberforce, T.; Alaswad, A.; Palumbo, A.; Dassisti, M.; Olabi, A.G. Advances in stationary and portable fuel cell applications. Int. J. Hydrogen Energy 2016, 41, 16509-16522. [CrossRef]

13. Elmer, T.; Worall, M.; Wu, S.; Riffat, S.B. Fuel cell technology for domestic built environment applications: State of-the-art review. Renew. Sustain. Energy Rev. 2015, 42, 913-931. [CrossRef]

14. Charalampides, G.; Vatalis, K.I.; Apostoplos, B.; Ploutarch-Nikolas, B. Rare Earth Elements: Industrial Applications and Economic Dependency of Europe. Procedia Econ. Financ. 2015, 24, 126-135. [CrossRef]

15. FC-HyGuide Project. Available online: http:/ / www.fc-hyguide.eu/ (accessed on 25 February 2019).

16. Mehmeti, A.; McPhail, S.J.; Ulgiati, S. Life cycle inventory data and metrics for high-temperature fuel cells: A streamlined decision-support tool and case study application. Energy 2018, 159, 1195-1205. [CrossRef]

17. Curran, M.A. Life Cycle Assessment Handbook: A Guide for Environmentally Sustainable Products; Scrivener Publishing LLC: Beverly, MA, USA, 2012.

18. Evangelisti, S.; Hardacre, C.; Catlow, R.; Tagliaferri, C.; Lettieri, P.; Collier, P.; Hutchings, G.; Davidson, M.; Brett, D.; Turner, N. Life Cycle Assessment of Emerging Catalyst Technologies: The Case of Polymer Electrolyte Membrane Fuel Cells. In Modern Developments in Catalysis; World Scientific (Europe): London, UK; pp. 289-312. ISBN 978-1-78634-121-1.

19. National Research Council. Minerals, Critical Minerals, and the U.S. Economy; The National Academies Press: Washington, DC, USA, 2008.

20. European Commission. The Raw Materials Initiative: Meeting Our Critical Needs for Growth And Jobs in Europe; European Commission: Brussels, Belgium, 2008.

21. Jin, Y.; Kim, J.; Guillaume, B. Review of critical material studies. Resour. Conserv. Recycl. 2016, 113, 77-87. [CrossRef]

22. Buchert, M.; Schüler, D.; Bleher, D. Critical Metals for Future Sustainable Technologies and their Recycling Potential; UNEP DTIE Öko-Institut: Freiburg im Breisgau, Germany, 2009.

23. Wouters, H.; Bol, D. Material Scarcity: An M2i Study; Materials Innovation Institute: Delft, The Netherlands, 2009.

24. U. S. Department of Energy. Critical Materials Strategy Report; U. S. Department of Energy: Washington, DC, USA, 2011.

25. British Geological Survey. Risk List 2015: An Updated Supply Risk Index for Elements or Element Groups That Are of Economic Value; British Geological Survey: Nottingham, UK, 2015; Volume 1.

26. U.S. Secretary of Defence. Strategic and Critical Materials 2015 Report on Stockpile Requirements under Secretary of Defense for Acquisition, Technology and Logistics; U.S. Secretary of Defence: Arlington, VA, USA, 2015.

27. National Science and Technology Council. Assessment of Critical Minerals: Screening Methodology and initial Application; National Science and Technology Council: Washington, DC, USA, 2016.

28. European Commission EU Critical Raw Materials. Available online: http://ec.europa.eu/growth/sectors/raw-materials/ specific-interest/critical_en (accessed on 1 December 2017).

29. European Commission. Critical Raw Materials for the EU; European Commission: Brussels, Belgium, 2010.

30. European Commission. Methodology for Establishing the EU List of Critical Raw Materials; European Commission: Brussels, Belgium, 2017.

31. European Commission. Study on the EU's List of Critical Raw Materials; Final Report; European Commission: Brussels, Belgium, 2020.

32. Wäger, P.A.; Lang, D.J.; Wittmer, D.; Bleischwitz, R.; Hagelüken, C. Towards a more sustainable use of scarce metals. A review of intervention options along the metals life cycle. Gaia 2012, 21, 300-309. [CrossRef]

33. Glöser, S.; Tercero Espinoza, L.; Gandenberger, C.; Faulstich, M. Raw material criticality in the context of classical risk assessment. Resour. Policy 2015, 44, 35-46. [CrossRef]

34. Graedel, T.E.; Barr, R.; Chandler, C.; Chase, T.; Choi, J.; Christoffersen, L.; Friedlander, E.; Henly, C.; Jun, C.; Nassar, N.T.; et al. Methodology of metal criticality determination. Environ. Sci. Technol. 2012, 46, 1063-1070. [CrossRef]

35. Daw, G. Security of mineral resources: A new framework for quantitative assessment of criticality. Resour. Policy 2017, 53, 173-189. [CrossRef]

36. Blengini, G.A.; Nuss, P.; Dewulf, J.; Nita, V.; Peirò, L.T.; Vidal-Legaz, B.; Latunussa, C.; Mancini, L.; Blagoeva, D.; Pennington, D.; et al. EU methodology for critical raw materials assessment: Policy needs and proposed solutions for incremental improvements. Resour. Policy 2017, 53, 12-19. [CrossRef] 
37. Knoeri, C.; Wäger, P.A.; Stamp, A.; Althaus, H.J.; Weil, M. Towards a dynamic assessment of raw materials criticality: Linking agent-based demand-With material flow supply modelling approaches. Sci. Total Environ. 2013, 461-462, 808-812. [CrossRef]

38. Bach, V.; Finogenova, N.; Berger, M.; Winter, L.; Finkbeiner, M. Enhancing the assessment of critical resource use at the country level with the SCARCE method-Case study of Germany. Resour. Policy 2017, 53, 283-299. [CrossRef]

39. Hofmann, M.; Hofmann, H.; Hagelüken, C.; Hool, A. Critical raw materials: A perspective from the materials science community. Sustain. Mater. Technol. 2018, 17, e00074. [CrossRef]

40. Buchholzer, M.L.; Kirch, M.; Kirchner, C.; Knoess, W. Toxicological assessment compilation of selected examples of raw materials for homeopathic medicinal products. Regul. Toxicol. Pharmacol. 2019, 103, 253-273. [CrossRef]

41. Goe, M.; Gaustad, G. Identifying critical materials for photovoltaics in the US: A multi-metric approach. Appl. Energy 2014, 123, 387-396. [CrossRef]

42. Agency for Toxic Substances and Disease Registry (ATSDR). Substance Priority List-Toxicity/Enviromental Scores. Available online: https: / /www.atsdr.cdc.gov/spl/resources/index.html (accessed on 11 November 2020).

43. Yazid, M.F.H.A.; Ta, G.C.; Mokhtar, M. Classified Chemicals in Accordance with the Globally Harmonized System of Classification and Labeling of Chemicals: Comparison of Lists of the European Union, Japan, Malaysia and New Zealand. Saf. Health Work 2020, 11, 152-158. [CrossRef]

44. Armstrong, V.; Karyakina, N.A.; Nordheim, E.; Arnold, I.; Krewski, D. Overview of REACH: Issues Involved in the Registration of Metals. Neurotoxicology 2020, 1-13. [CrossRef]

45. Graedel, T.E.; Harper, E.M.; Nassar, N.T.; Reck, B.K. On the materials basis of modern society. Proc. Natl. Acad. Sci. USA 2013, 112, 6295-6300. [CrossRef] [PubMed]

46. Nassar, N.T.; Du, X.; Graedel, T.E. Criticality of the Rare Earth Elements. J. Ind. Ecol. 2015, 19, 1044-1054. [CrossRef]

47. European Commission. Report on Critical Raw Materials and the Circular Economy Part 1/3; European Commission: Brussels, Belgium, 2018; ISBN 0-7803-8350-8.

48. Hodnik, N.; Baldizzone, C.; Polymeros, G.; Geiger, S.; Grote, J.P.; Cherevko, S.; Mingers, A.; Zeradjanin, A.; Mayrhofer, K.J.J. Platinum recycling going green via induced surface potential alteration enabling fast and efficient dissolution. Nat. Commun. 2016, 7, 13164. [CrossRef] [PubMed]

49. Perez, J.P.H.; Folens, K.; Leus, K.; Vanhaecke, F.; Van Der Voort, P.; Du Laing, G. Progress in hydrometallurgical technologies to recover critical raw materials and precious metals from low-concentrated streams. Resour. Conserv. Recycl. 2018, 142, 177-188. [CrossRef]

50. Ding, Y.; Zhang, S.; Liu, B.; Zheng, H.; Chang, C.C.; Ekberg, C. Recovery of precious metals from electronic waste and spent catalysts: A review. Resour. Conserv. Recycl. 2019, 141, 284-298. [CrossRef]

51. Løvik, A.N.; Hagelüken, C.; Wäger, P. Improving supply security of critical metals: Current developments and research in the EU. Sustain. Mater. Technol. 2018, 15, 9-18. [CrossRef]

52. Development of Eco-Design Guidelines for FCH Products. Available online: https://ec.europa.eu/info/funding-tenders/ opportunities/portal/screen/opportunities/topic-details/fch-04-3-2020 (accessed on 11 November 2020).

53. Development and Validation of Existing and Novel Recycling Technologies for Key FCH Products. Available online: https: / / ec.europa.eu/info/funding-tenders/opportunities/portal/screen/opportunities/topic-details/fch-04-4-2020 (accessed on 11 November 2020).

54. HyTechCycling Project: New Technologies And strategies for Fuel Cells and Hydrogen Technologies in the Phase of Recycling and Dismantling. Available online: http:/ / hytechcycling.eu/ (accessed on 25 February 2019).

55. Férriz, A.M.; Bernad, A.; Mori, M.; Fiorot, S. End-of-life of fuel cell and hydrogen products: A state of the art. Int. J. Hydrogen Energy 2018, 1-8. [CrossRef]

56. Lotrič, A.; Stropnik, R.; Mori, M.; Drobnič, B.; Jurjevčič, B.; Sekavčnik, M. D2.1 Assessment of Critical Materials and Components in FCH Technologies: New Technologies and Strategies for Fuel Cells and Hydrogen Technologies in the Phase of Recycling and Dismantling; European Commission: Brussels, Belgium, 2017.

57. United Nations. Globally Harmonised System of Classification and Labelling of Chemicals; Economic Commission for Europe: Geneva, Switzerland, 2015.

58. European Chemicals Agency (ECHA). European Regulation on Registration, Evaluation, Authorisation and Restriction of Chemicals (REACH). Available online: https:/ / echa.europa.eu/regulations/reach/legislation (accessed on 10 November 2020).

59. Asian Metal-The World Metal Information Center. Available online: http://www.asianmetal.com/ (accessed on 31 January 2018).

60. London Metal Exchange: Reference Prices for Metals. Available online: https://www.lme.com/Metals (accessed on 22 January 2018).

61. Prices of Elements and Their Compounds. Available online: https://en.wikipedia.org/wiki/Prices_of_elements_and_their_ compounds (accessed on 1 December 2016).

62. Nicoletti, G.; Arcuri, N.; Nicoletti, G.; Bruno, R. A technical and environmental comparison between hydrogen and some fossil fuels. Energy Convers. Manag. 2015, 89, 205-213. [CrossRef]

63. Stropnik, R.; Lotrič, A.; Montenegro, A.B.; Sekavčnik, M.; Mori, M. Critical materials in PEMFC systems and a LCA analysis for the potential reduction of environmental impacts with EoL strategies. Energy Sci. Eng. 2019, 1-21. [CrossRef] 
64. Lotrič, A.; Sekavčnik, M.; Kuštrin, I.; Mori, M. Life-cycle assessment of hydrogen technologies with the focus on EU critical raw materials and end-of-life strategies. Int. J. Hydrogen Energy 2020. [CrossRef]

65. International Organisation for Standardisation. ISO 14040, Environmental Management—Life Cycle Assessment-Principles and Framework. 2006. Available online: https://www.iso.org/standard/37456.html (accessed on 27 February 2021).

66. International Organisation for Standardisation. ISO 14044: Environmental management—Life Cycle Assessment-Requirements and Guidelines. 2006. Available online: https:/ /www.iso.org/standard/38498.html (accessed on 27 February 2021).

67. European Commission-Joint Research Centre-Institute for Environment and Sustainability. General Guide for Life Cycle Assessment_Detailed Guidance; Institute for Environment and Sustainability: Ispra, Italy, 2010; ISBN 978-92-79-19092-6.

68. Masoni, P.; Zamagni, A. Guidance Document for Performing LCAs on Fuel Cells and Hydrogen Technologies (FC-HyGuide). Available online: http://hytechcycling.eu/wp-content/uploads/FC-Guidance-Document.pdf (accessed on 27 February 2021).

69. Baitz, M.; Makishi, C.; Kupfer, T.; In, J.F.-; Schuller, O.; Kokborg, M.; Köhler, A.; Thylmann, D.; Stoffregen, A.; Schöll, S.; et al. GaBi thinkstep Database \& Modelling Principles. Available online: https:/ / www.gabi-software.com/fileadmin/GaBi_Databases / GaBi_Modelling_Principles_2017.pdf (accessed on 27 February 2021).

70. Ecoinvent 3.6: The Latest Version of the Ecoinvent Database Features more than 2200 New and 2500 Updated Datasets. Available online: https: / / www.ecoinvent.org/database/older-versions/ecoinvent-36/ecoinvent-36.html (accessed on 20 November 2020).

71. Thinkstep Gabi, GaBi Databases: Professional Database, Sphera Solutions GmbH, Germany. Available online: http:/ /www.gabisoftware.com/databases/gabi-databases/professional/ (accessed on 22 December 2020).

72. Staffell, I.; Ingram, A.; Kendall, K. Energy and carbon payback times for solid oxide fuel cell based domestic CHP. Int. J. Hydrogen Energy 2012, 37, 2509-2523. [CrossRef]

73. Mori, M.; Stropnik, R.; Lotrič, A.; Drobnič, B.; Sekavčnik, M. LCA Approach in the end of Life Cycle of FCH Technologies; HyTechCycling GA: No. 700190; University of Ljubljana: Ljubljana, Slovenia, 2017.

74. European Commission, European Platform on Life Cycle Assessment: Environmental Footprint. Available online: https: / / eplca.jrc.ec.europa.eu / /EnvironmentalFootprint.html (accessed on 10 November 2020).

75. Zampori, L.; Pant, R. Suggestions for Updating the Product Environmental Footprint (PEF) Method; Publications Office of the European Union: Luxembourg, 2019.

76. GaBi Database 2020 LCI Documentation. Available online: http://www.gabi-software.com/international/support/gabi/gabidatabas\$cdotp\$10\$-\$20-lci-documentation/ (accessed on 22 December 2020).

77. WHO-Regional Office for Europe. Air Quality Guidelines for Europe; WHO Regional Office for Europe: Copenhagen, Denmark, 2000. 